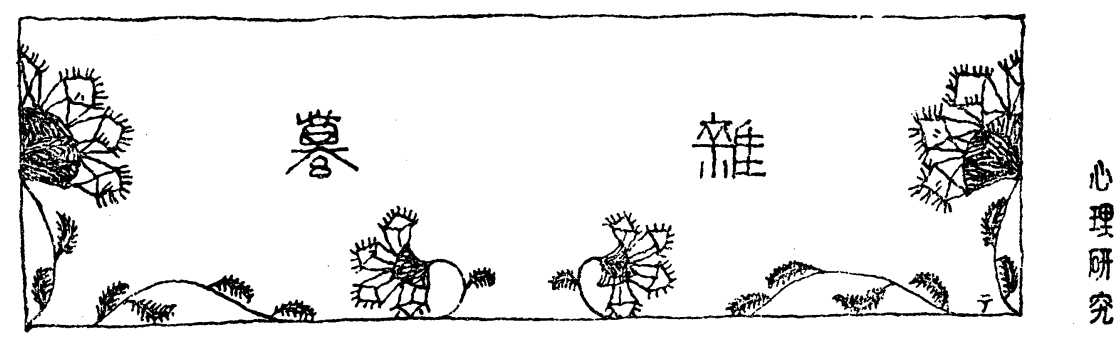

\title{
三二の例析分禹精の話种本日 京左田神ルトゥド篗
}

述精雄向るにな才殊研疑一心神

心神神に。天古い》に究問本理話》

る分話出從犋代と卜此にで調學等口

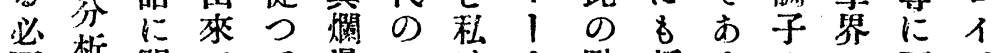

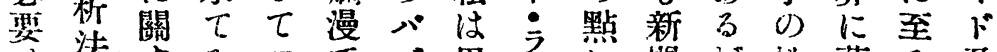

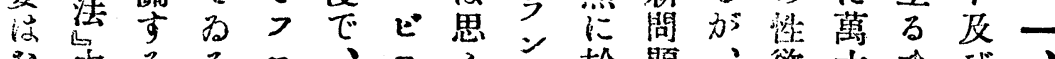

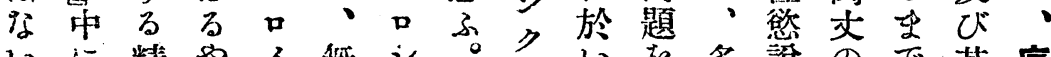

いに精や亿無亣。いを多說ので其序

○紹神うト暗・它て提方で氣精の

介分に二に俩

析思派抹太

虹のふの殺

$\tau$ 主。精 或 有

あ要さ神性臘

る 點 引 分 改等

加㤝し析作 の

ら・ $\tau$ の 被

已こ好

今にれ資點

更久等料加、

此 保 の $\varepsilon$ 尠

處良桐しな述

に英話 $て$ 方

繰 氏、、や古

返の殊全亏心

し著にくで文

書㹧誂あけ

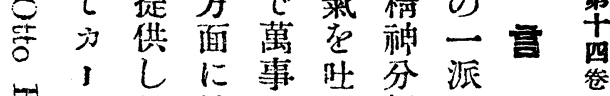

行捗蛋心析 0

焉号功解法學

ブ續て泝わ居者

等
要
恶

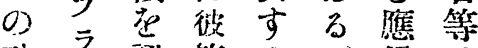

功今認等る分角糔

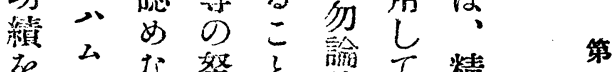

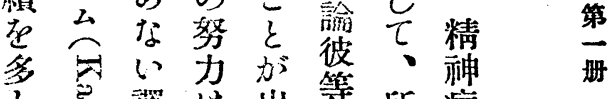

之总譯出等所病

し〉に:來加謂は全

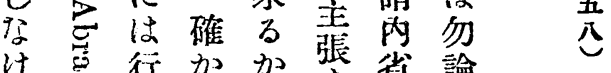

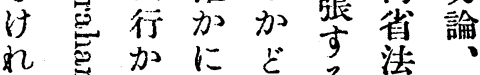

ば据な神うる势夢

な芨心話架㚾毒劇 


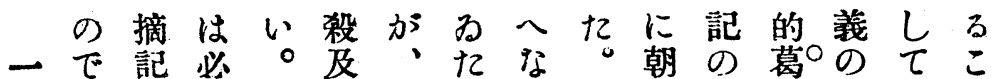

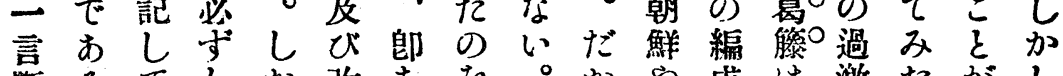

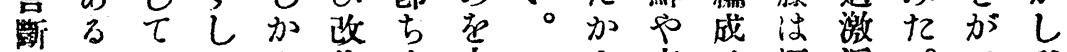

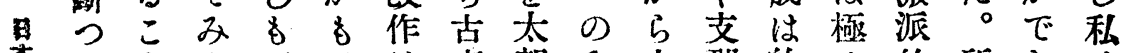

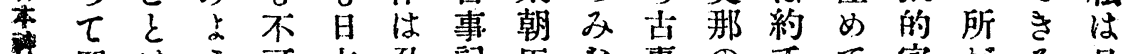

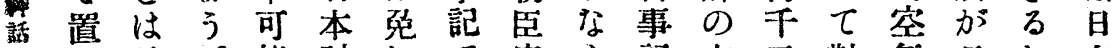

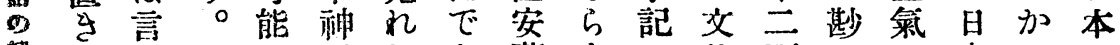

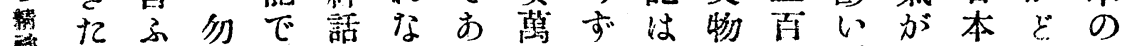

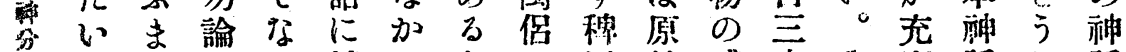

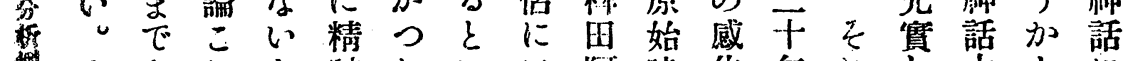

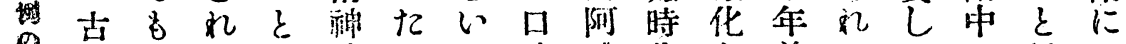

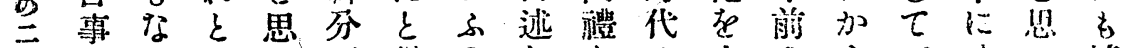

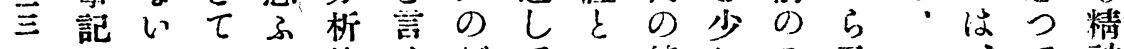

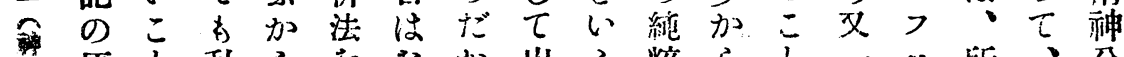

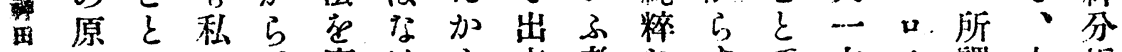
文での、應けら來者な宗で方イ謂古析 性古試三用れ、上が物受、に目事法

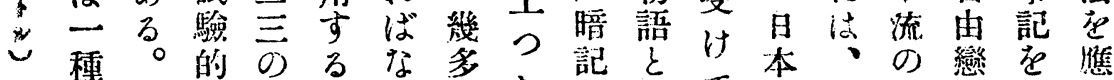

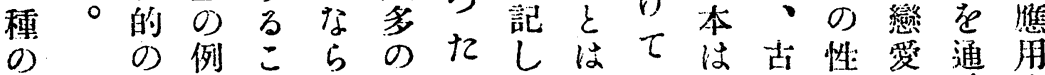

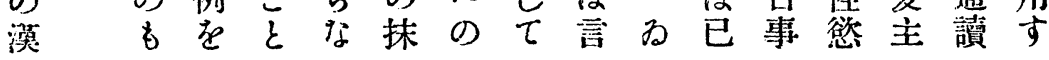

がれかちの算頁 瓘との多句は參の日 に心錯くに隨照所本

策了繰の方分謂神

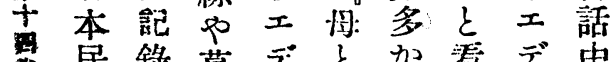

要民錄葛

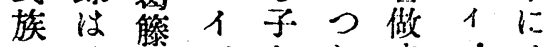

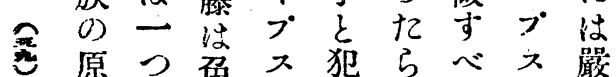

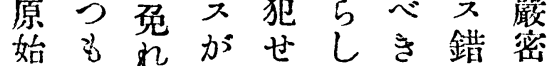

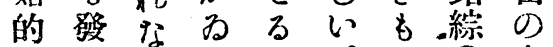

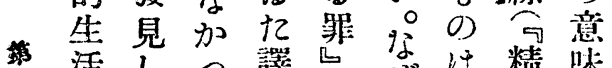

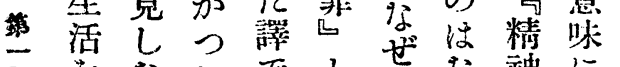

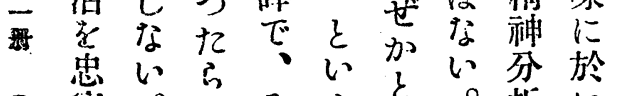

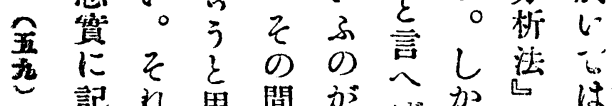
記思間方芯㤎忠

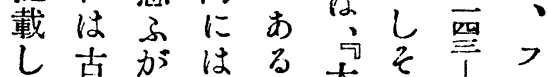

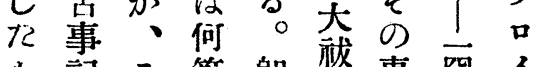

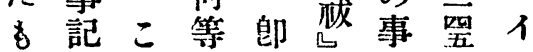

主の事るる0交 に俗記。が外體 用語以䈍!にに み譯なに難: 古な 二る る龊解訓、つ こ私 》川广 告加の玄點古为

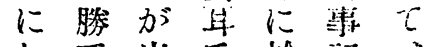
し手出氏於記。 化版が心本顧 0)修さ罚七本る で正れに售難 あし $\tau$ 俗原豈解

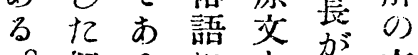
佃るに主臎齐 所。譯主翋䆘 をだし†しで

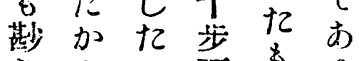
な.

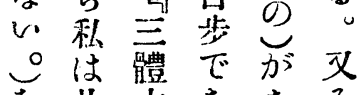

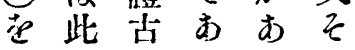


思ななる功れ犬卆の時が原原はの

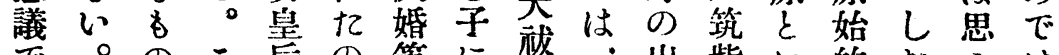
でのこ后の等に晸・出紫的か及は は況でれはだのはに世籍のふ氣しなっな

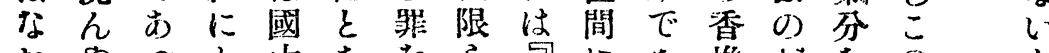

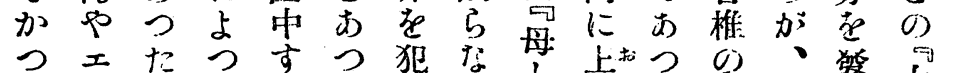

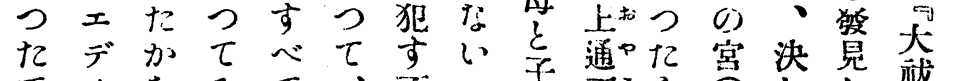

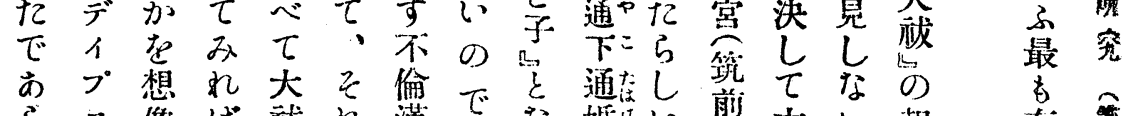

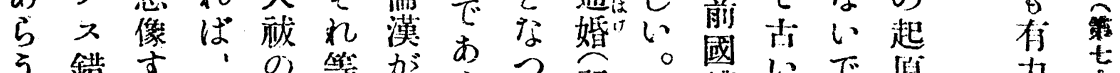
引錯市门等が方親无糟いで原

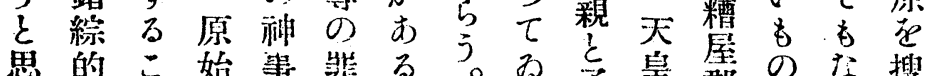
思的こ始事韭る る。 る

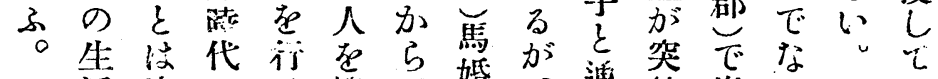
活決の性? 婚方聥然崩心所み

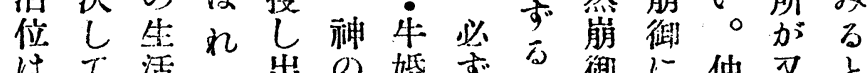

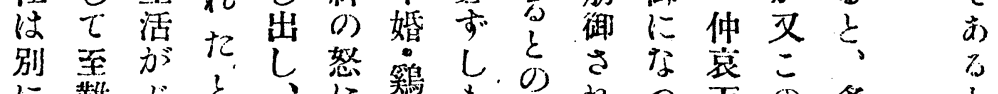
に薙

小

と理 磷 力 な 理 由 霊 $\vec{\tau}$ 筫

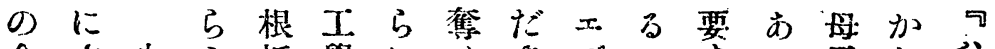
命立少う柢學には多デこ等つ子し心フ

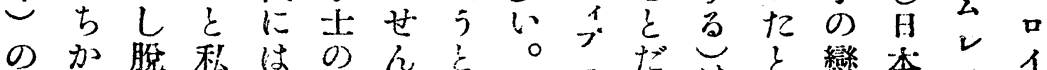

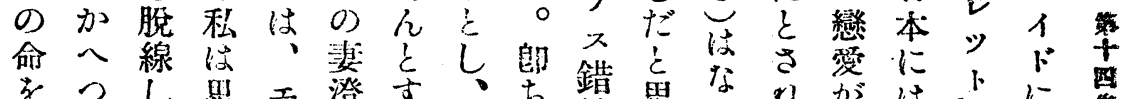

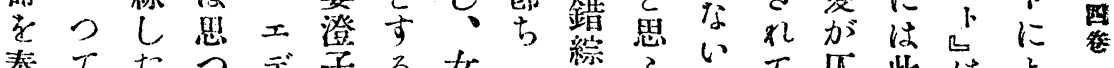

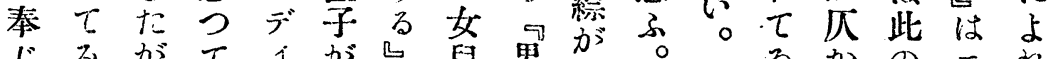

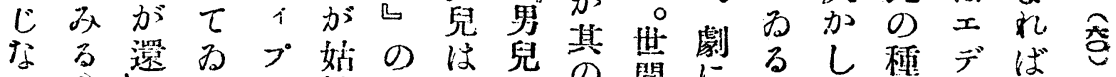

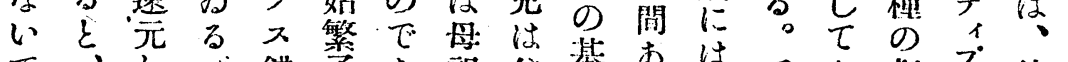

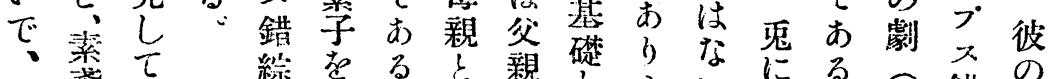

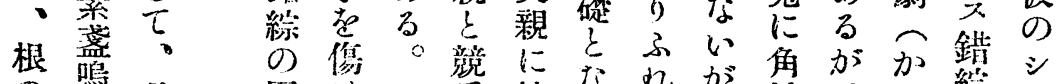

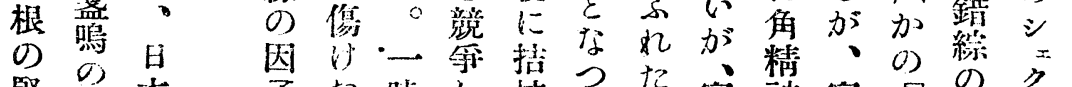

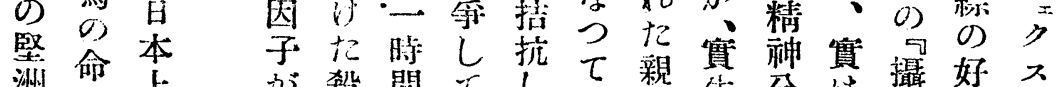

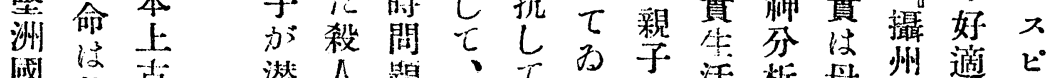

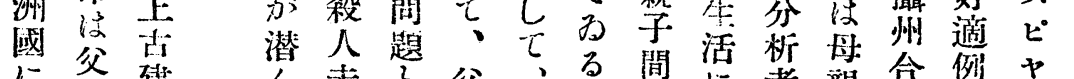

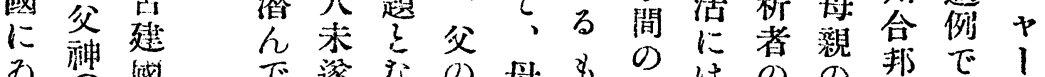

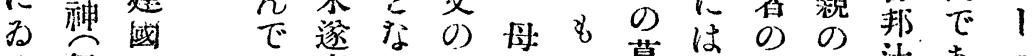
ま伊のわ事つ愛の葛随注謀过あの

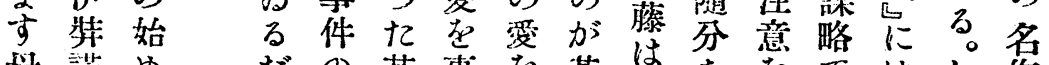

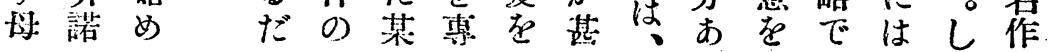


で錯てれ命な子法あ少話、殘し語で神

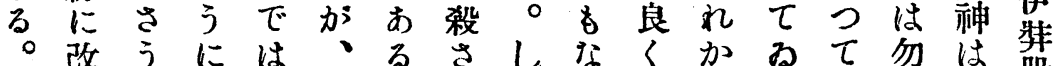
星作し改多のうか心似引方諭怒册

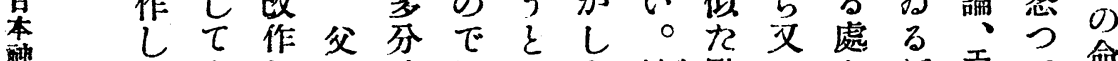

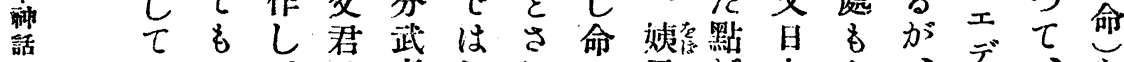
の みつては者な视君加本あ、吉、

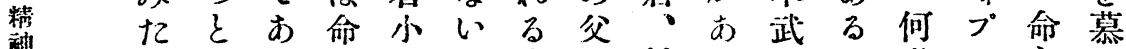

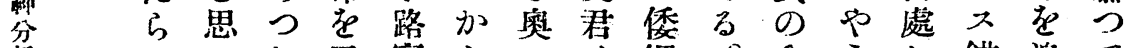

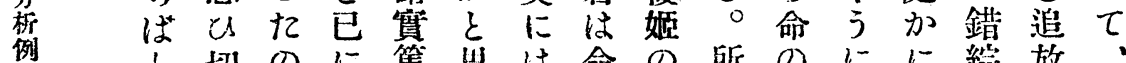

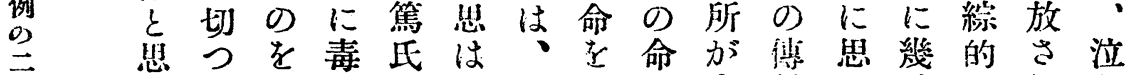

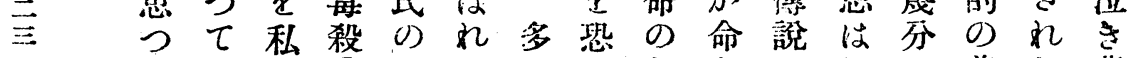

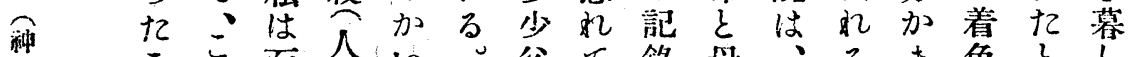

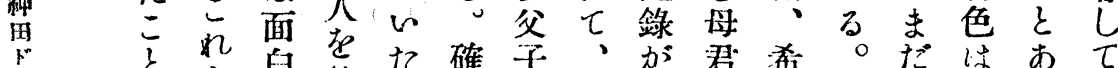

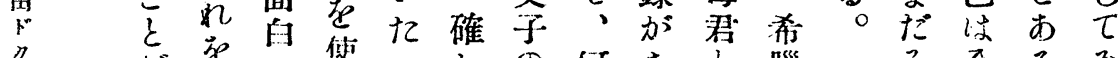

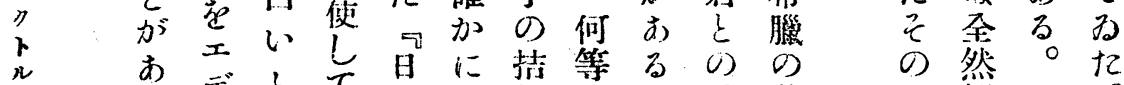
几 市

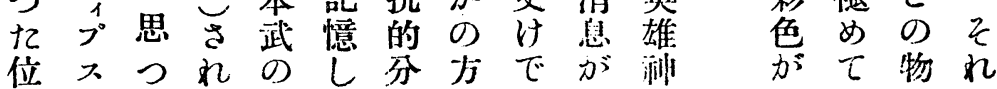

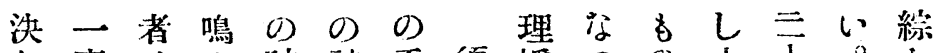

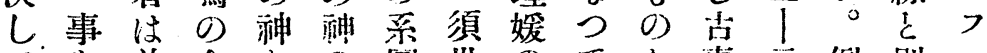

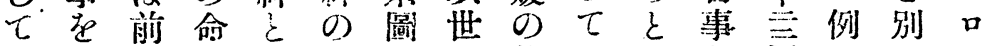
正み者之の嫡は理物る、記挐入夕人

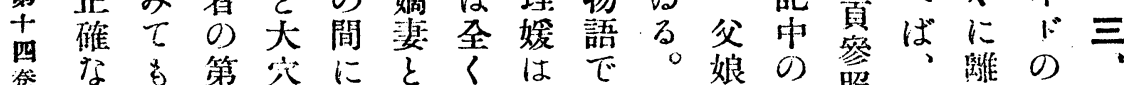

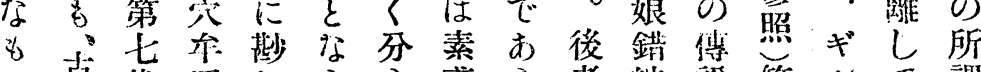

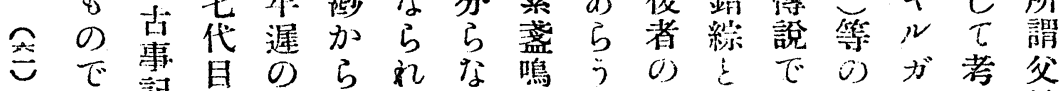

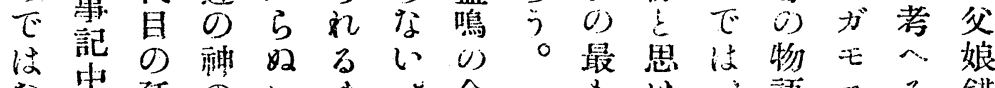

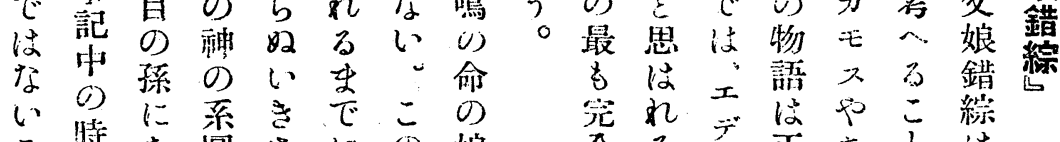

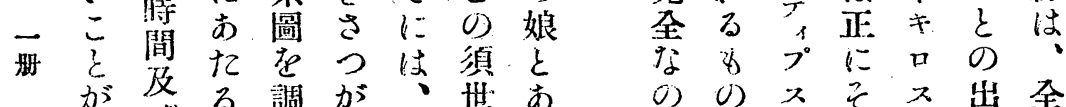
六分宁神調が公理る

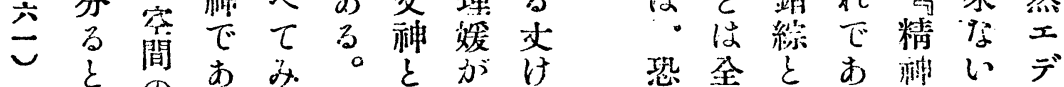

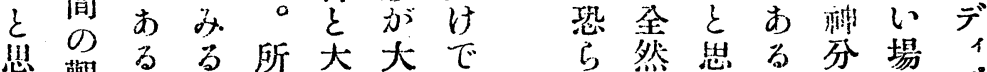

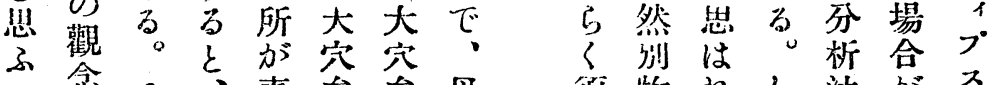

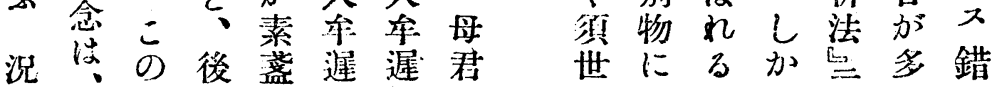


領に須蚛言るはに入相てのの知ん 布授世のそはら莘中方娼夾所大記れや をけ理簇のれれ原さ方へらに范しな系

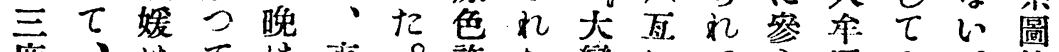

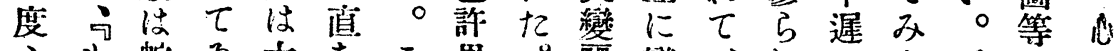

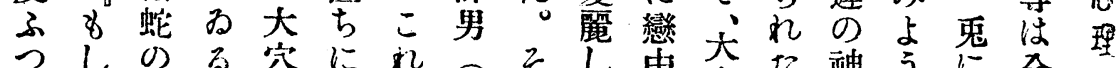

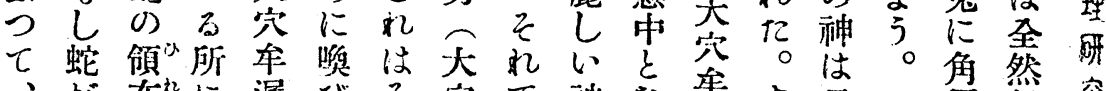

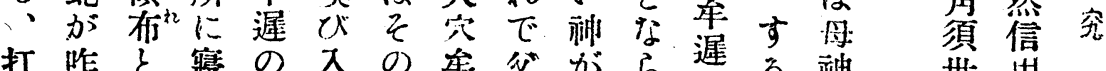
打咋々雙 の

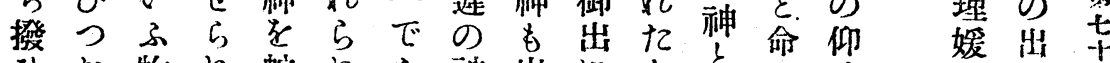

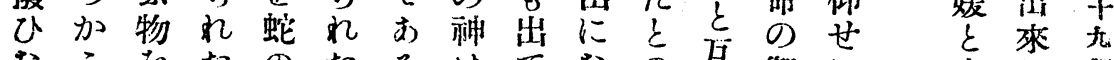

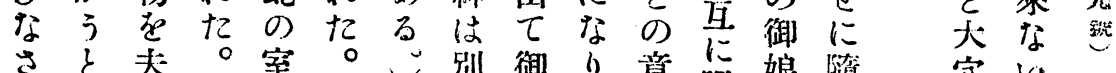

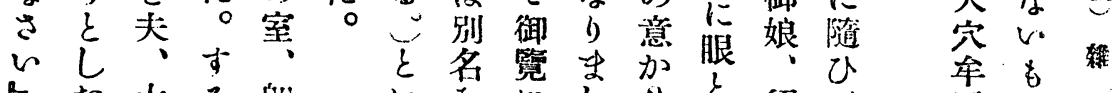

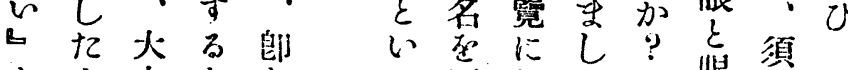

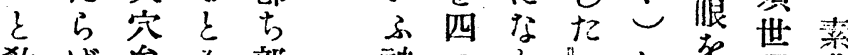

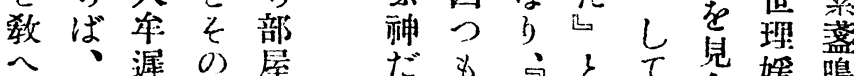

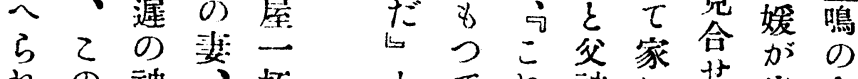

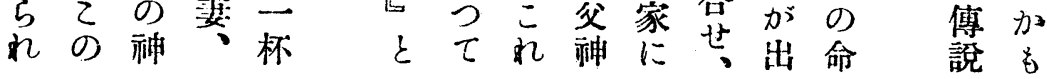

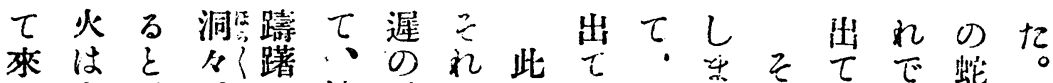
七上、兄燒神老度來前た可來神は大

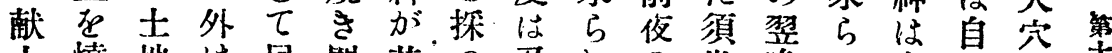

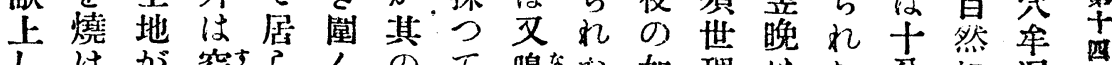

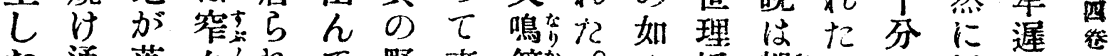

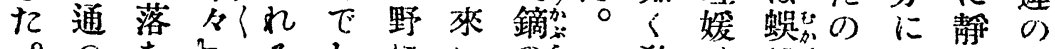

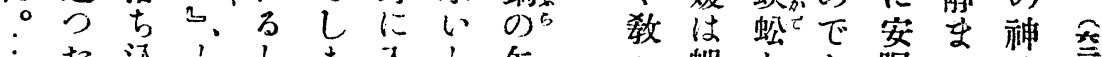

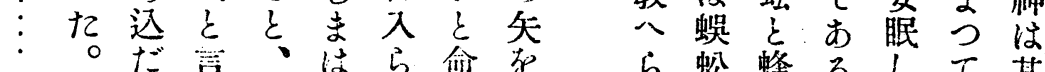

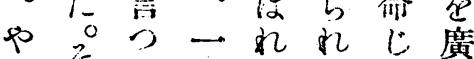

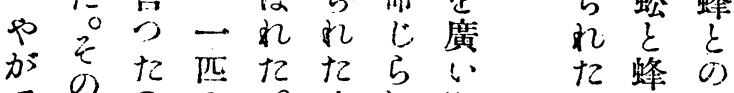
$\tau$ 中 0 \% 時设野
之星飞鼠神扛原

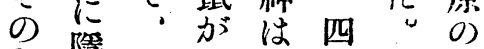

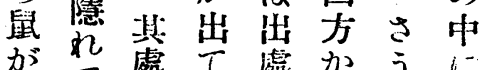

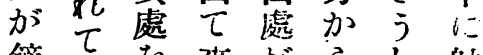

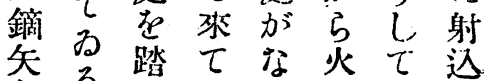

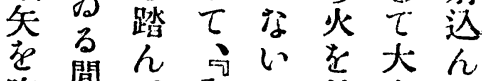

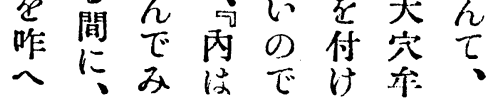
12 䗋
○室
乙傾比
㮌入
でをれ
及御方
衤渡视
整记
$k=$

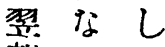
ᄂ $\tau$ 其
朝っ加
何通
翌骂策
胡害红冽
整 8 है
事视念
に尔机
蛇 少の
室尼で
䂟。多
5飞?

痋 9 寒

0)

命多

o) 
武媛を家

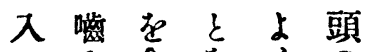

た が死 具

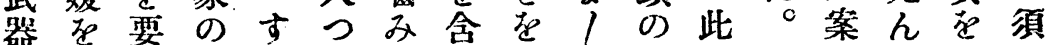

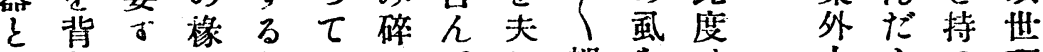

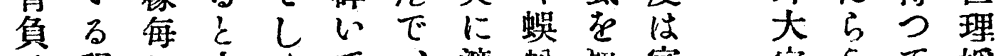
日天ひ程に大出て、渡蚣取家

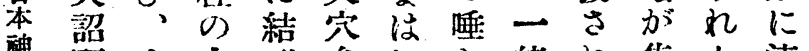

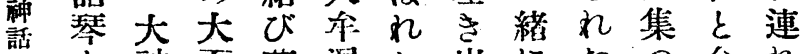
のと神石著避て出にたつ愈れ

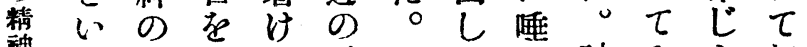

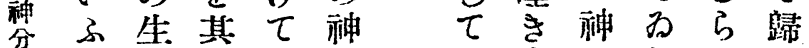

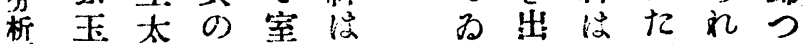

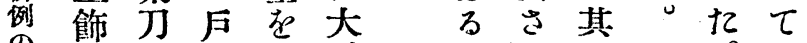

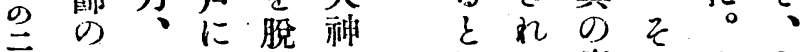
三琴生立け照る蛽のそ大

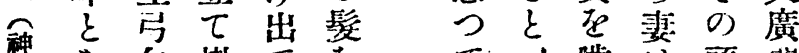

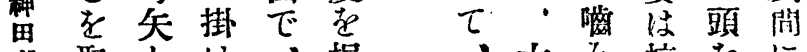

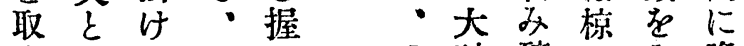
出的五つ威神碎のみ喚 しふ:百て 心はき實れび 七大須人、蜈主ば

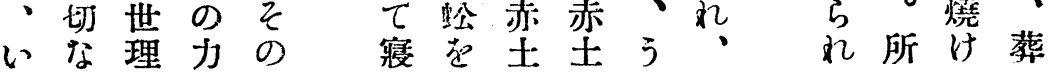

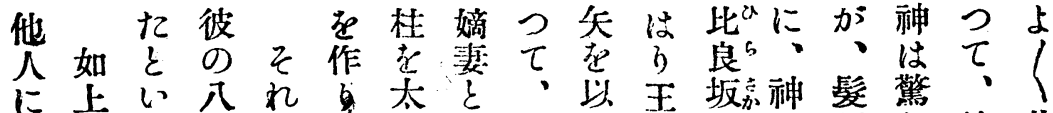

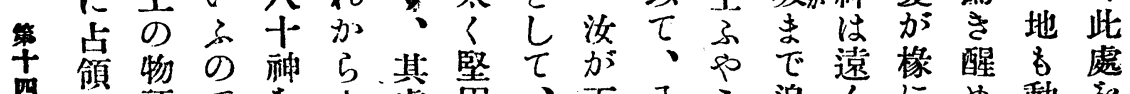

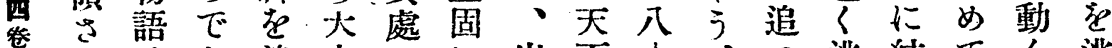

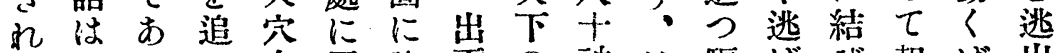
套る、る。全居建雲の种泣驅げび起ば出

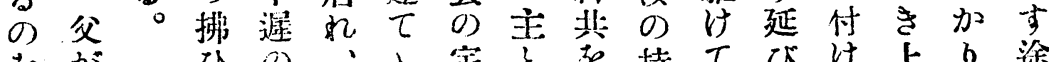

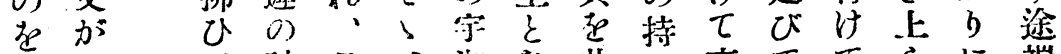

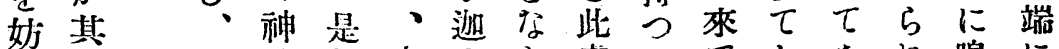

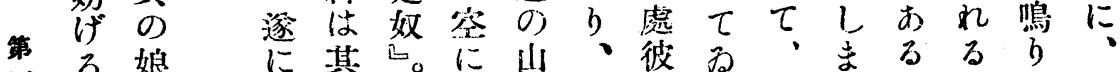

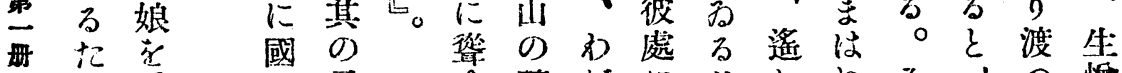

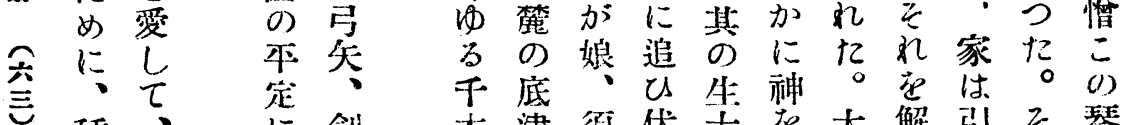
種、に劍 々 着等 なの手持 蜼 䬶 a 題· れ

木津須伏太在大解沪飞琴 高岩世召見神加引の

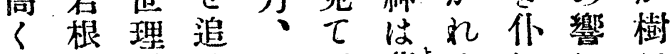

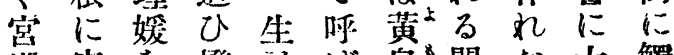

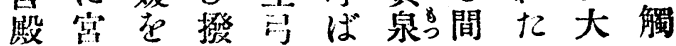


示記中れ分生樣類で一を

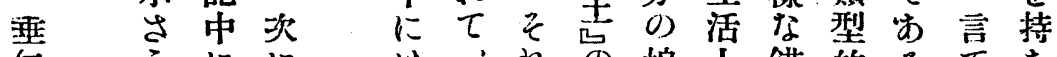

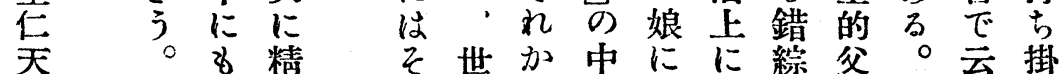

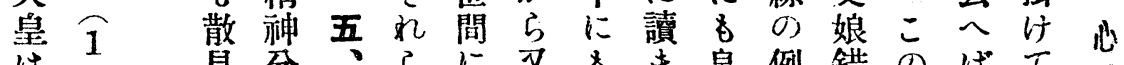

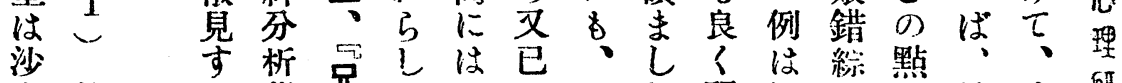

本沙る學兄い甘にこ机現原の势娘全研

彦本二者籍例息述のいは始好らの々究

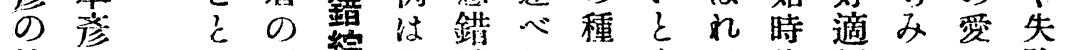

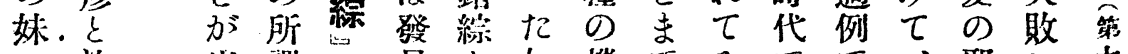

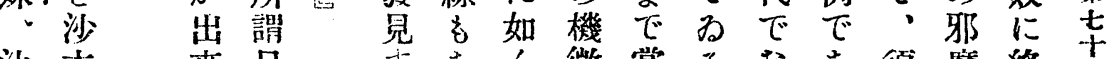

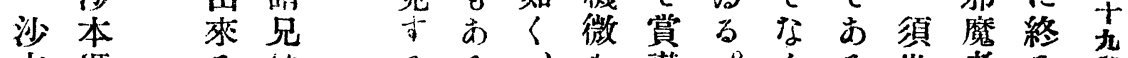

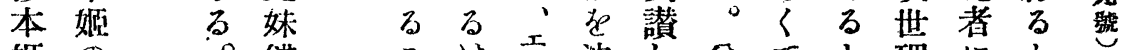

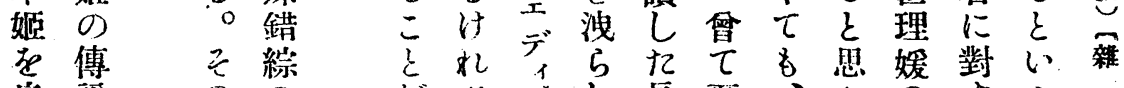

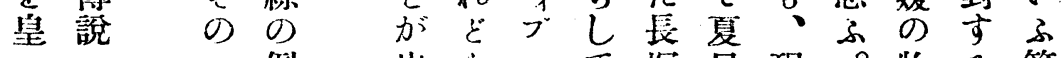

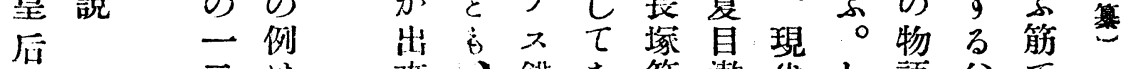

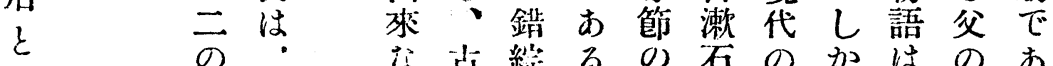

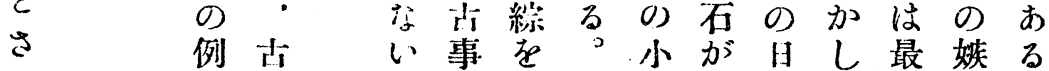

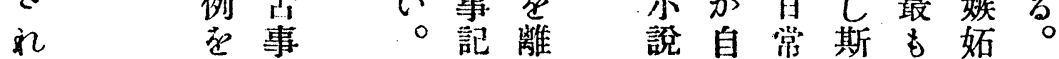

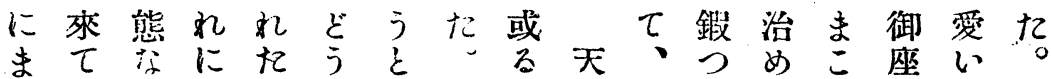

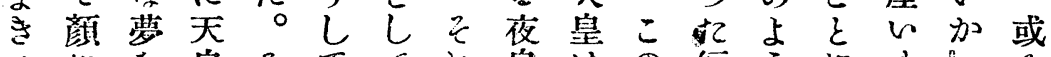

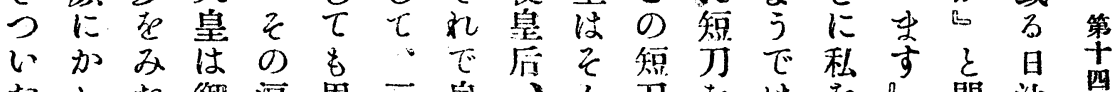

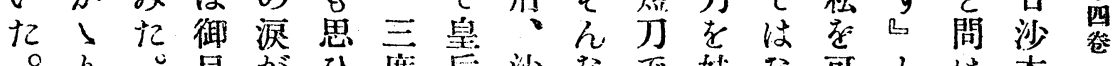

○り目がひ度曆沙なで妹な可飞は本

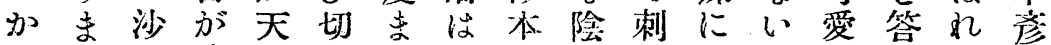

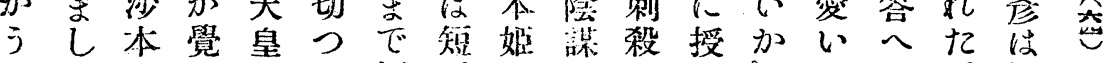

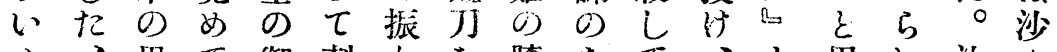

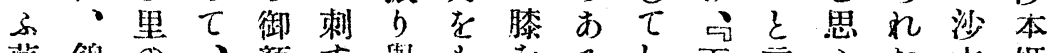

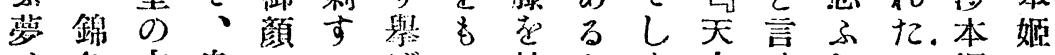

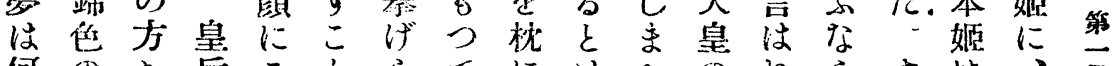

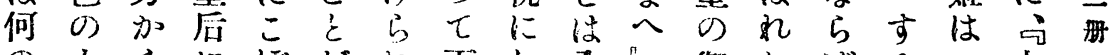

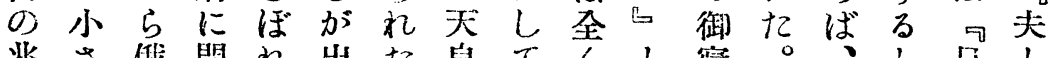

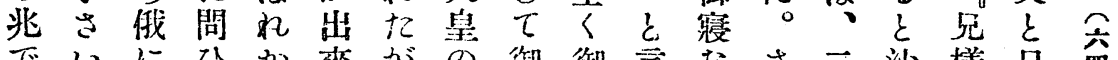

でいにひか來がの御御言なさ二沙樣兄畕

あ蛇雨王了な衰御眠存性つ亏人本加々 らががふついし頸り知れ九しで崖可は

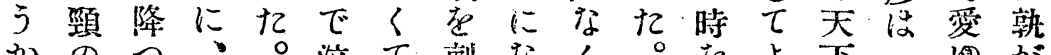

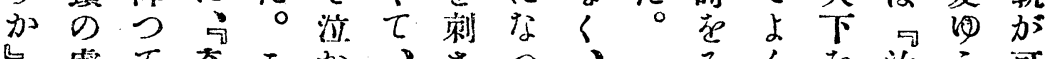

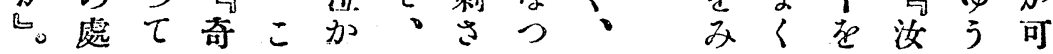




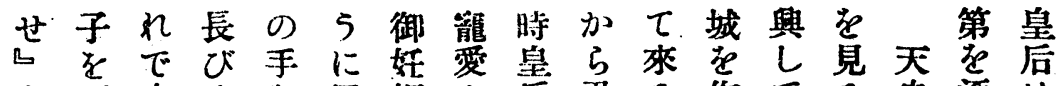
と天皇々を思娠さ后忍る作てる皇逐は

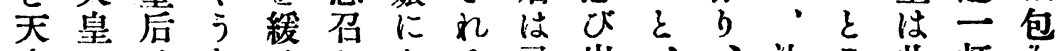

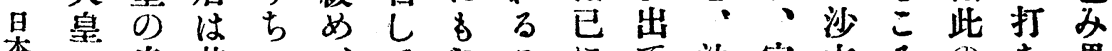
榊に皇其に、て应にに沙官本万吃果

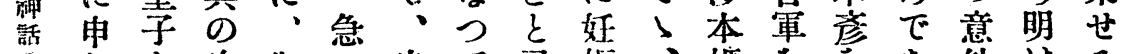

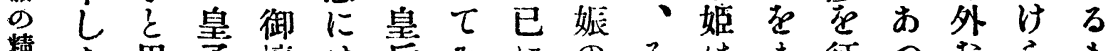
橉あ思子襄は后るにのそはま征つならを

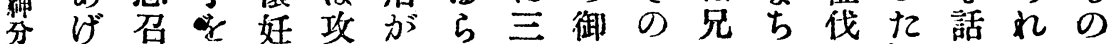

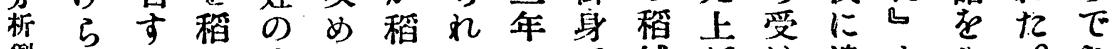
誃记な城皇ら城るにで城が遣子を。

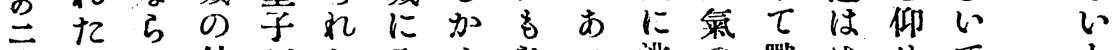

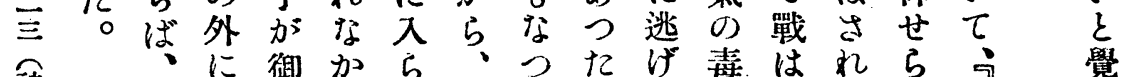

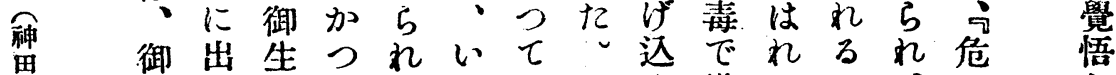

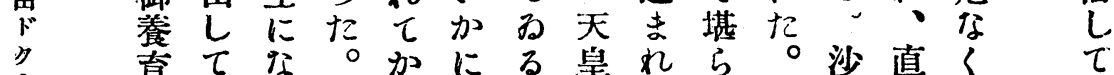

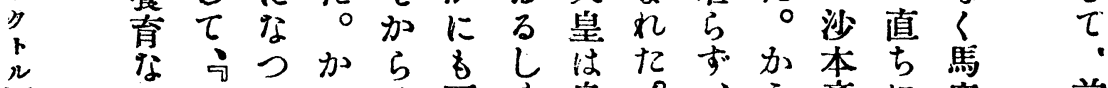

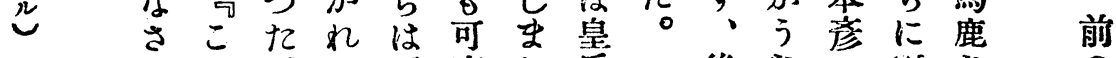

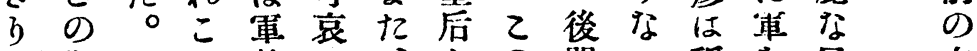

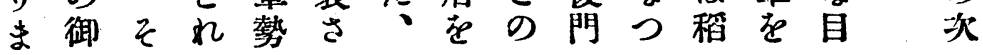

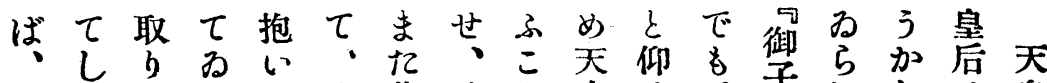
玉ま奉机七す着腕皇せ手子れしは皇 第のつら力城つ衣の表のつで受てて暮は

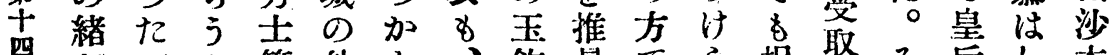

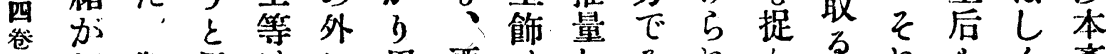

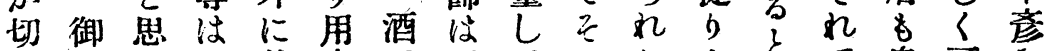

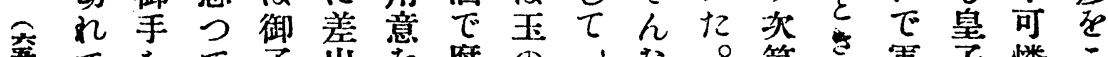
$\tau$ 在 $\tau 子$ 出腐

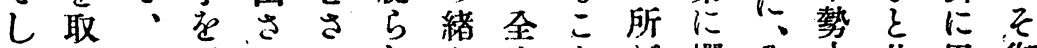
ま 5 御受れれしを子を方㩧之中共思御

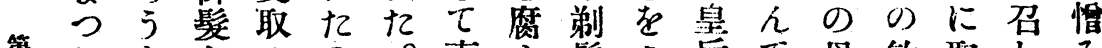

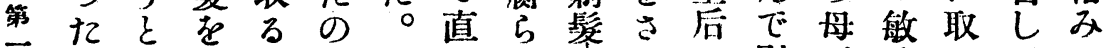

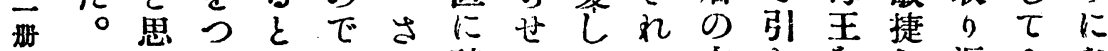

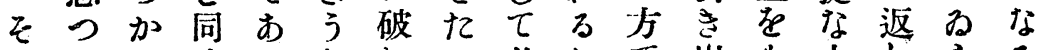

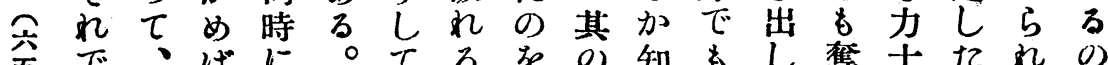

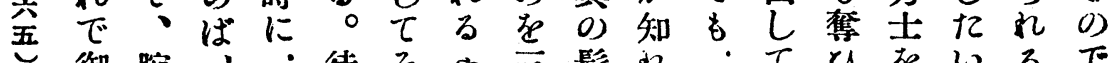

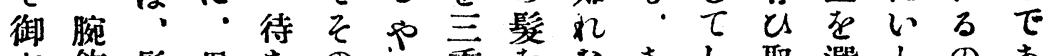

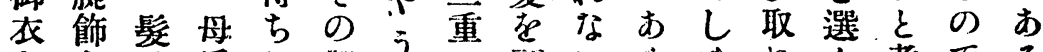

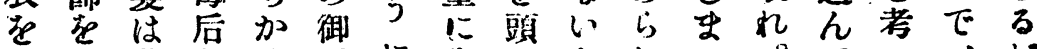

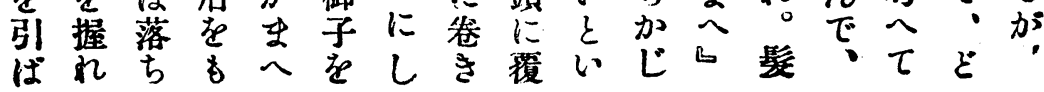


住后きをし返とつ御子べし士城つ

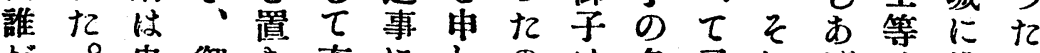
が。申御き育にし出名子礼性逃か

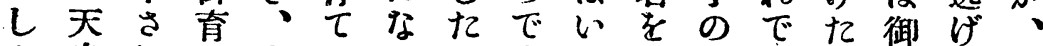
上皇れて大たつがす何名天。子込衣

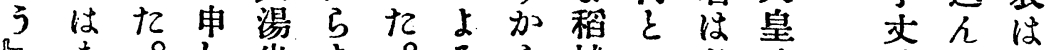
るま。し坐よ。万弓城う必は破

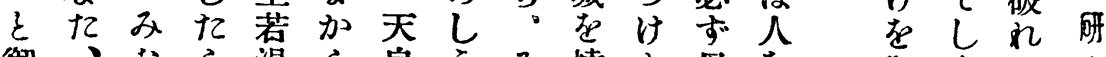

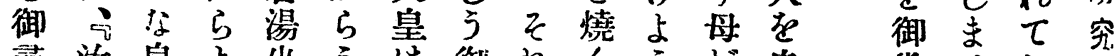

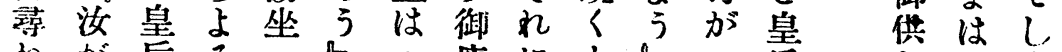

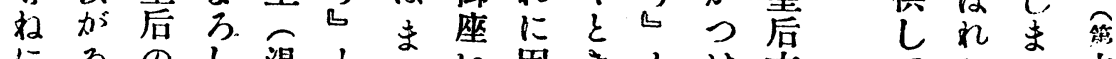
なな

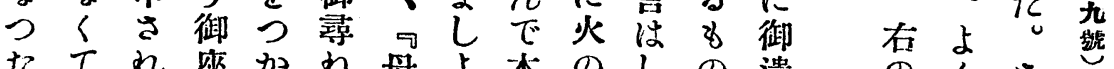

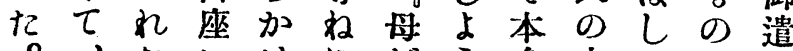

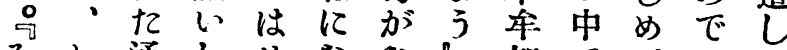
そわ通しせな广ら智飞王あに

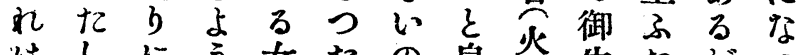

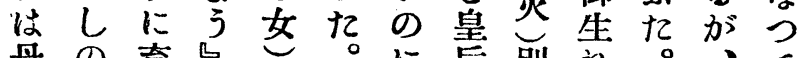

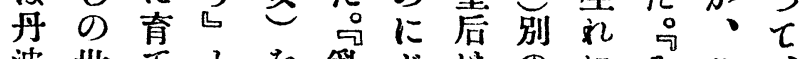

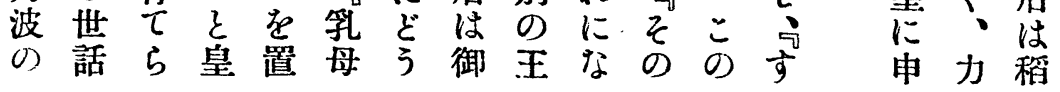

の纪あれ全全 兄の枺り沙召が产

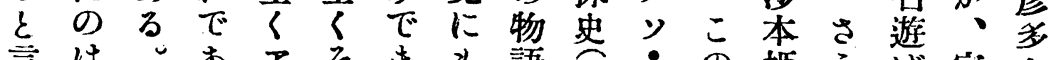

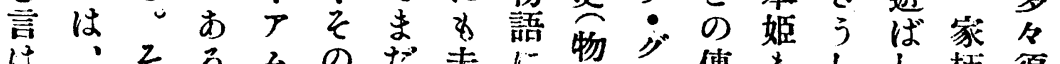

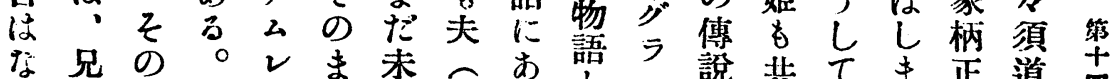

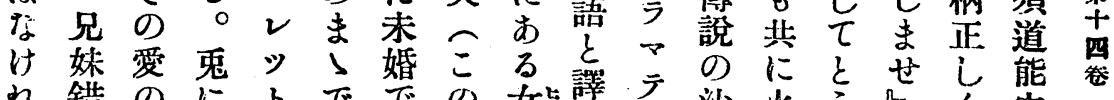

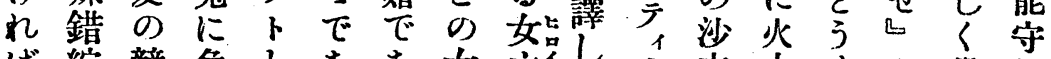

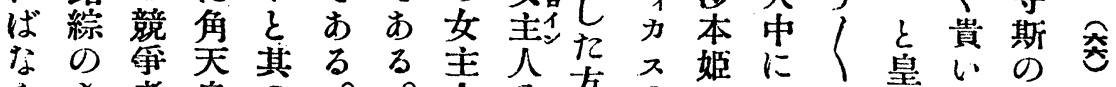

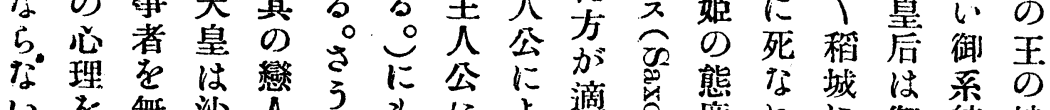

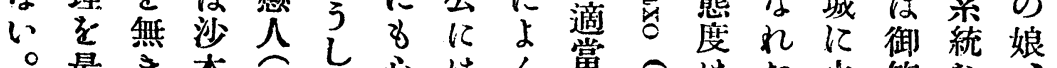

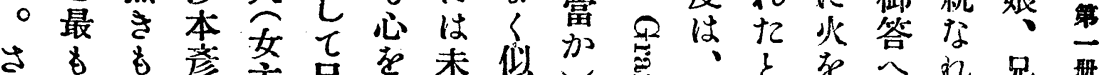

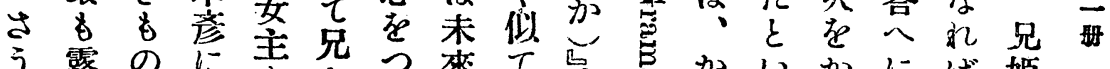

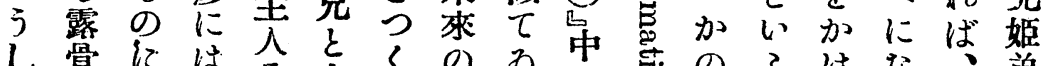

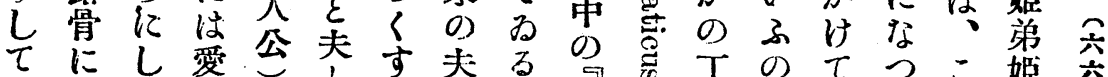

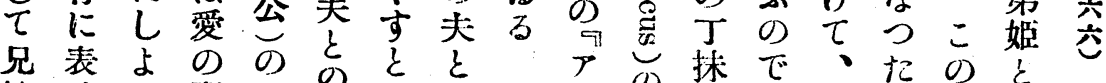

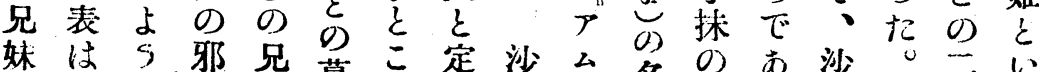

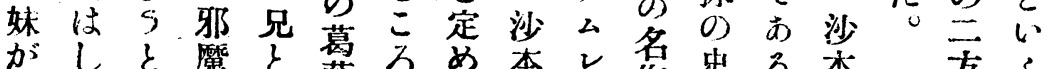

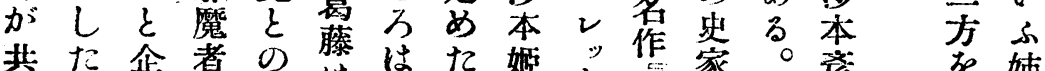

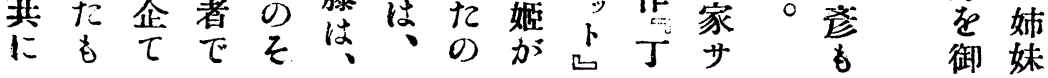


のいのる極かの兄關か位

で。でをめを所妹係れ允

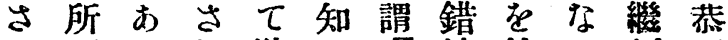
人茫る れ狹れ錯綜結いが天

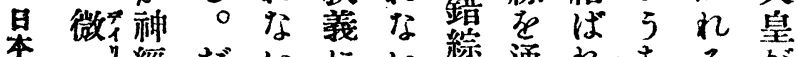

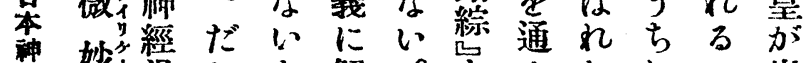

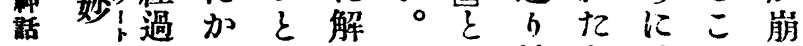

のに敏ら治しし言越と御

縺威なこ、た加人しあす同にに

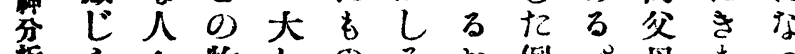

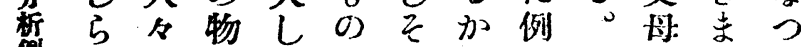

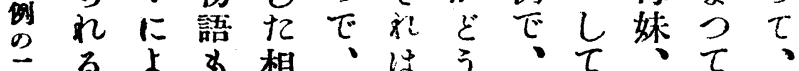

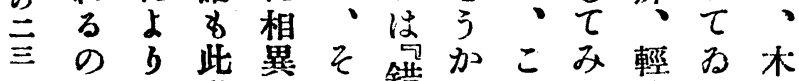

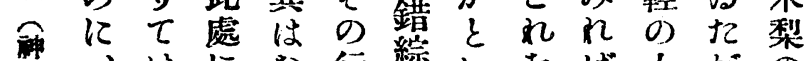

男、岕にな行綜心学ば太方の

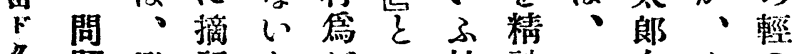

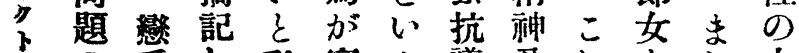

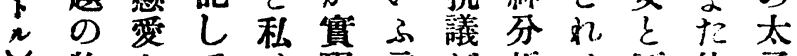

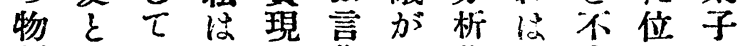
語い及思艺葉あ學全倫に力;

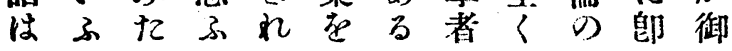

日级火 本貫中 獨 現に 特 己 死 2) $\checkmark$ i七 中 の の桀市 傳梨みあう 境 の元る 輕差: 态支礼系 子当簿

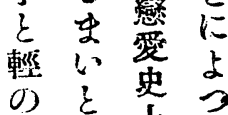
太态等

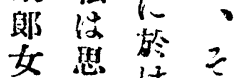
女思活

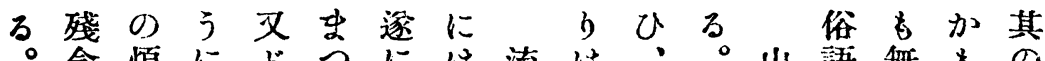
念煩にどつには流は、・山語無をの

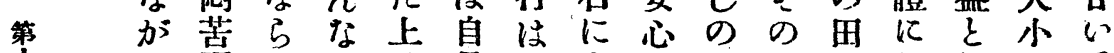

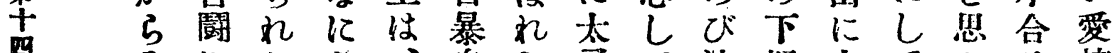

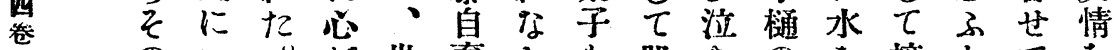

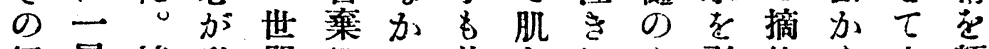

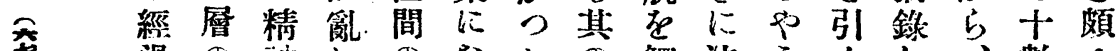

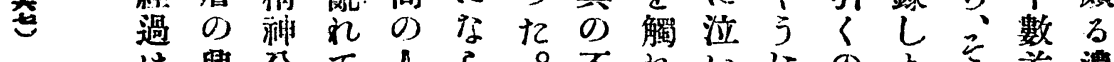

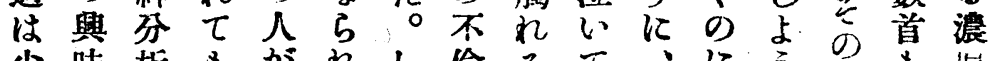

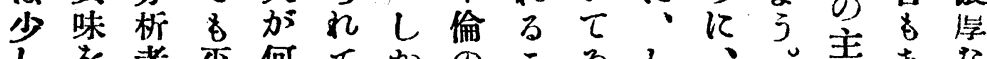

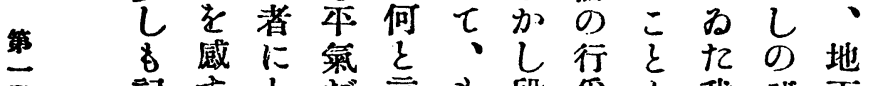

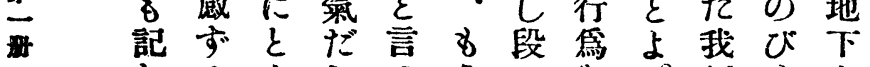

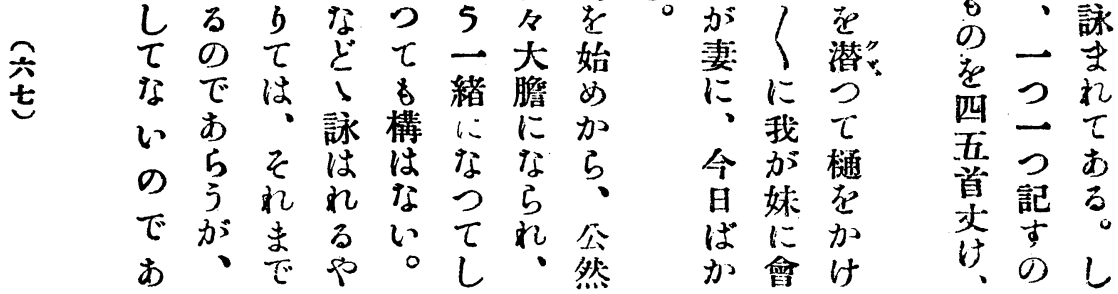


いま時て、だ桃生大湯は子太态始

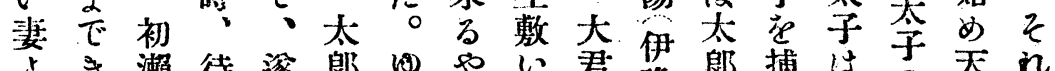

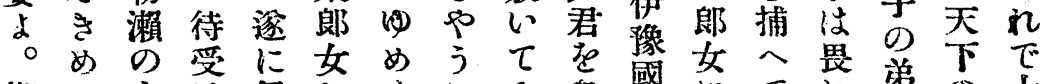

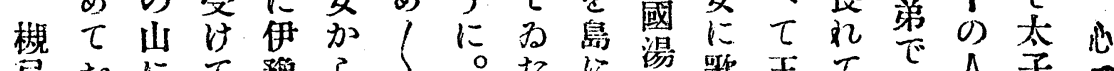

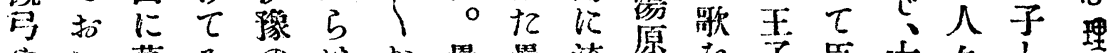

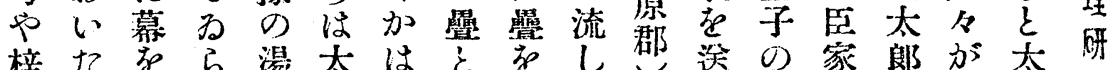

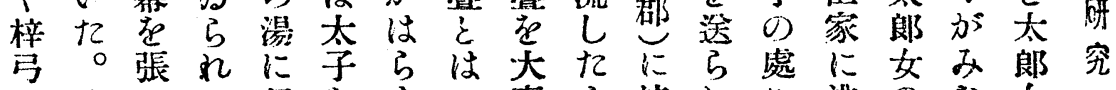

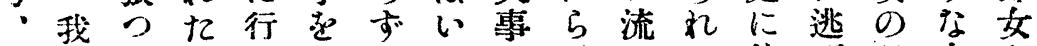

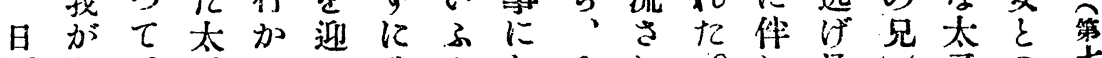

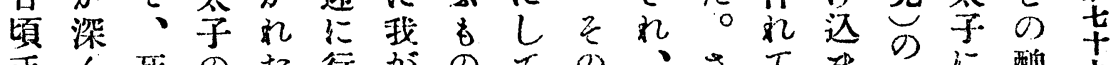

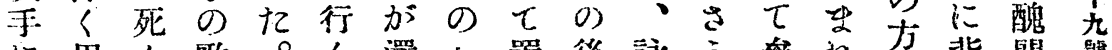

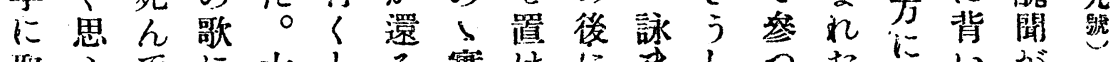

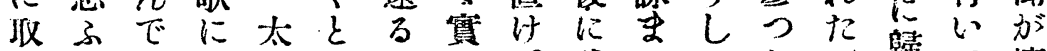

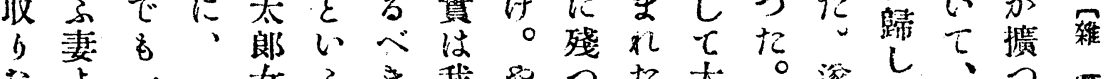

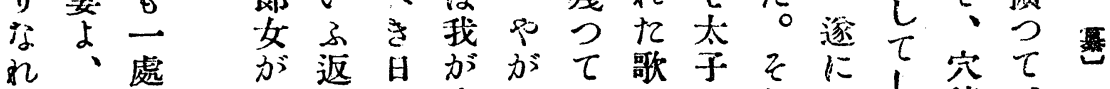

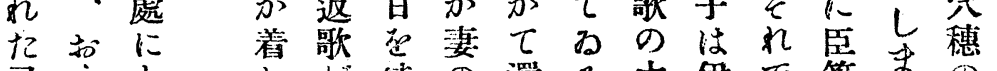
弓方沙加待の還方中伊で等告の百

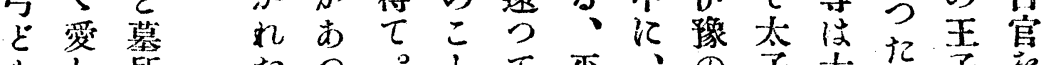

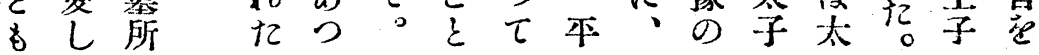

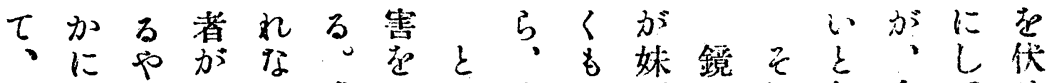

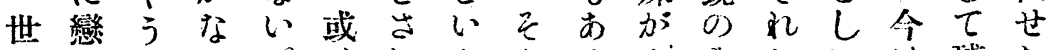

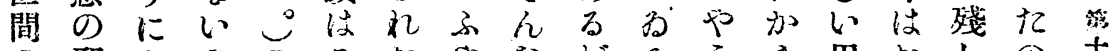
の邪

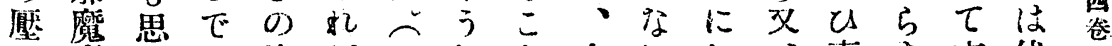

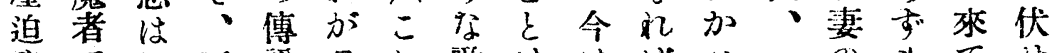

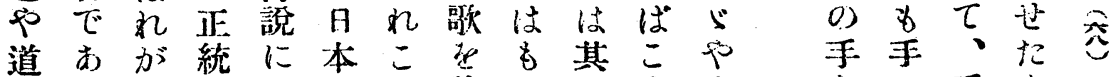

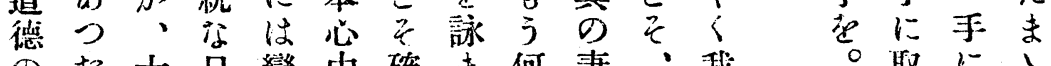
のた太兄戀中確ま何妻: 我。取にり 呵の子妹の史かれを古故加 責みの錯競のにて子此鄕妻:

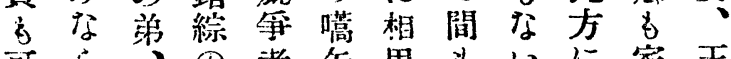
可ら、の渚矢思名心に家玉

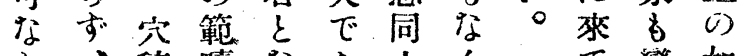

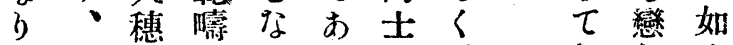
に太心をるっの、してく 手手脱心伅心二末美 應に子しき加中人僈し

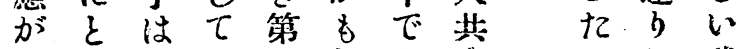
あう確る兰知古自加代我

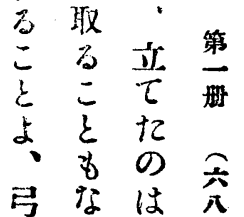
写少立 $12 \xi \frac{1}{\tau}$ な思た $\begin{array}{lll}1 & 2 & 2 \\ 1 & j & \vdots\end{array}$ 
を出自ばのし知くしつ媘人のて

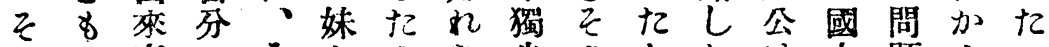

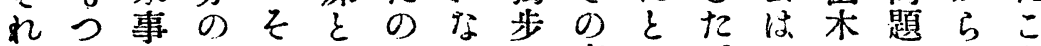

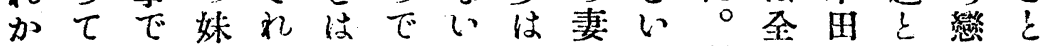

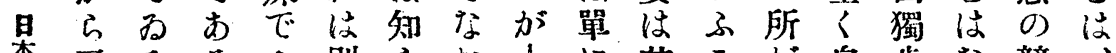

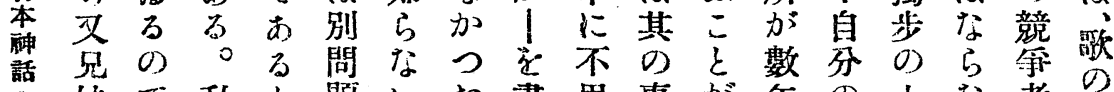

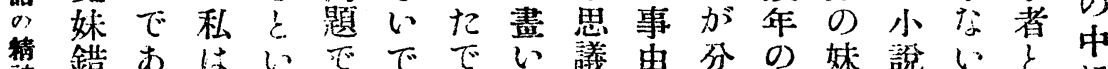

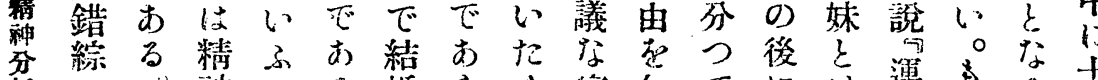

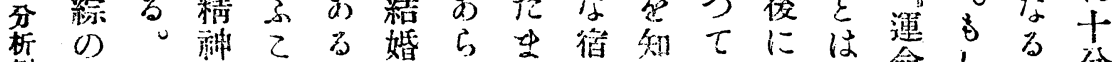

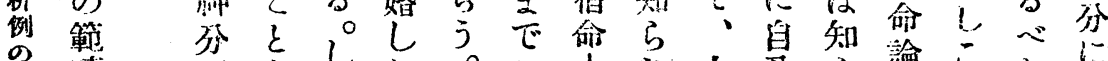

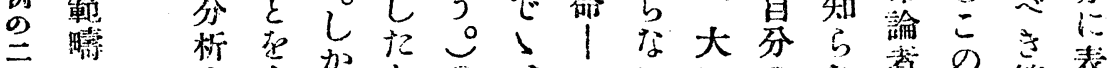
三心王士

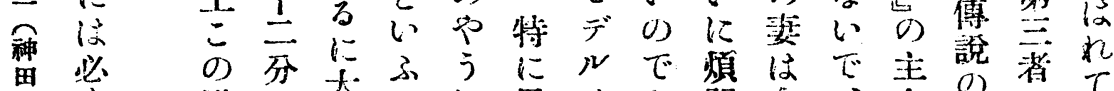

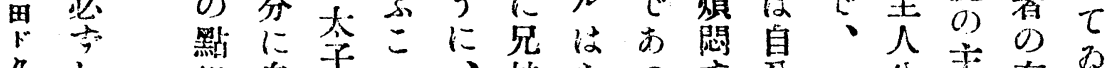

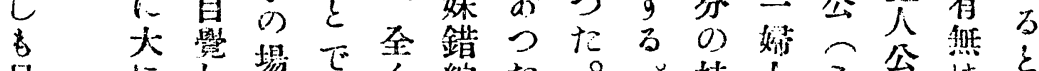

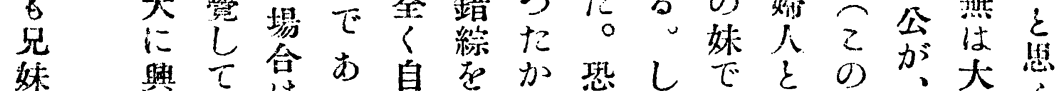

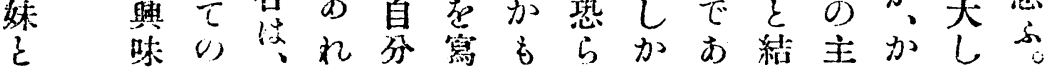

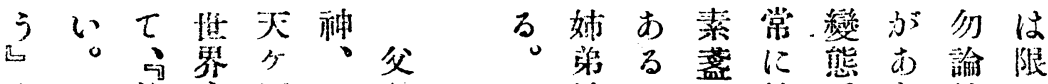

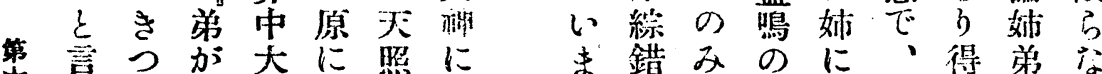
士 方大に照に。错みのに、得弟字

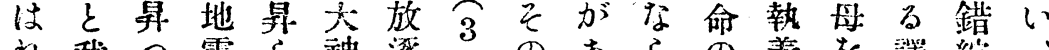

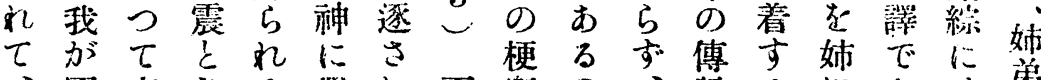

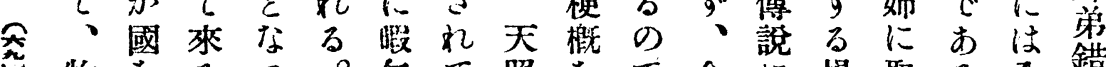

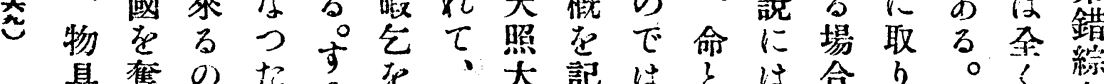

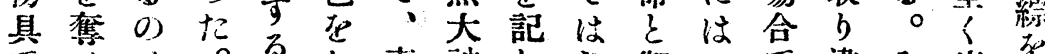

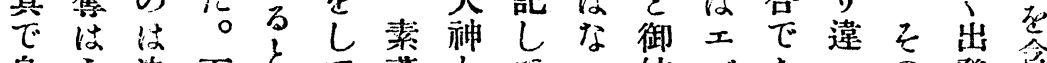

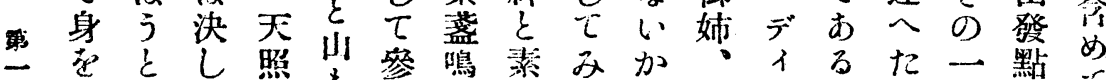

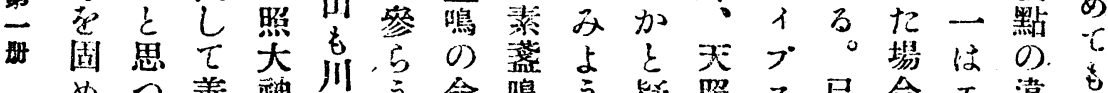

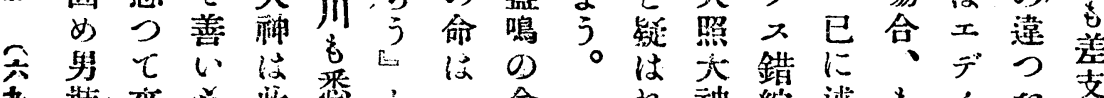

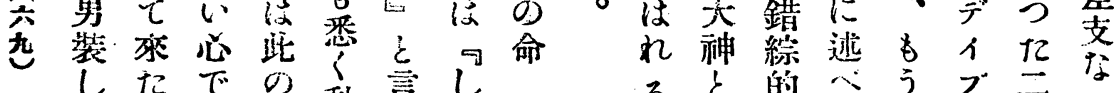

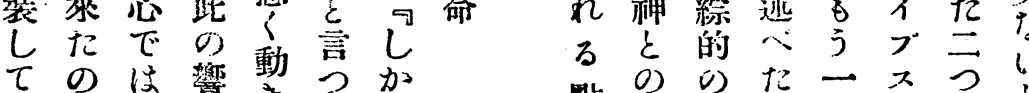

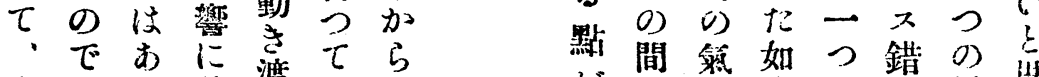

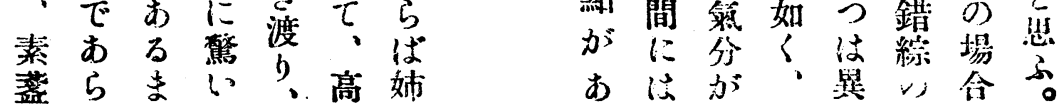




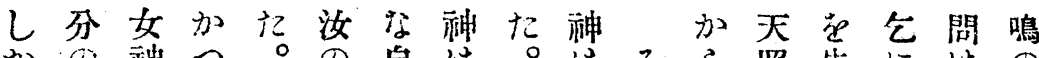
分の神つ。の自は。は照告にはの

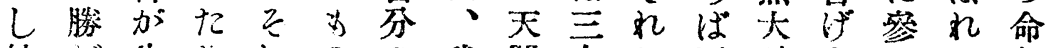

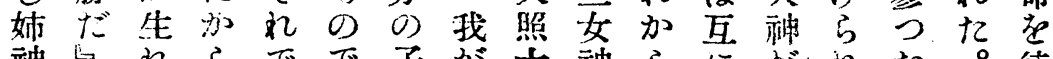

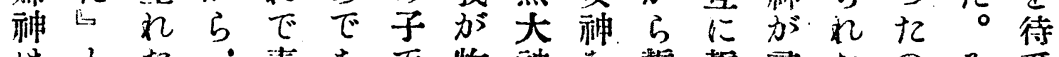

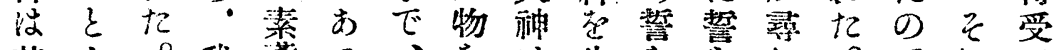

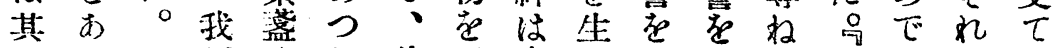

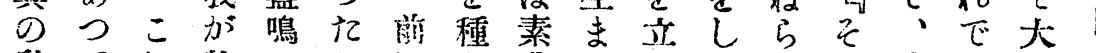

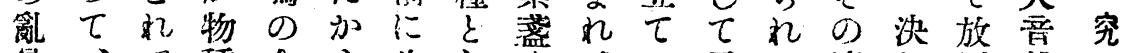

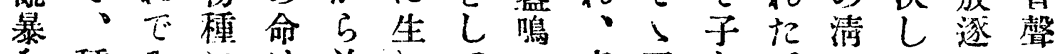

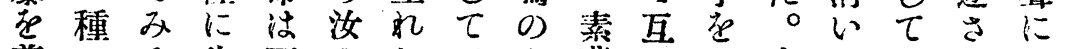

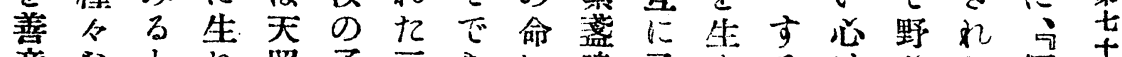

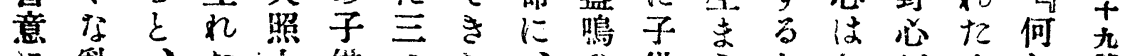

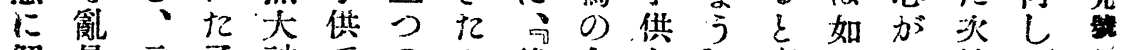
解暴言子神でのす後命を素何 あ第に

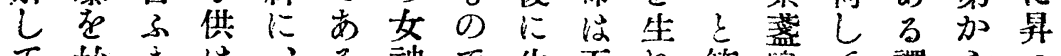

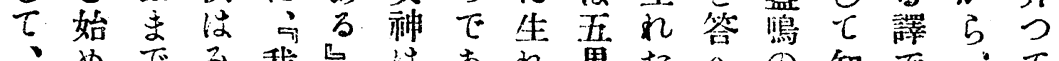

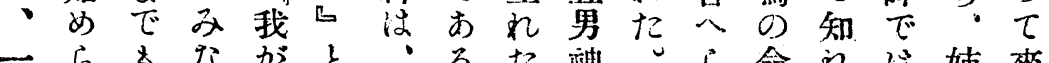

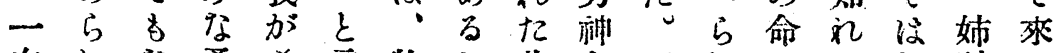

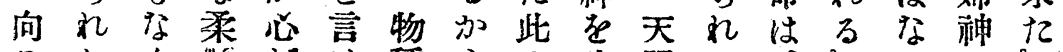

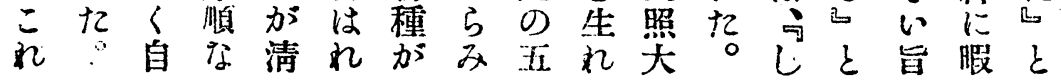

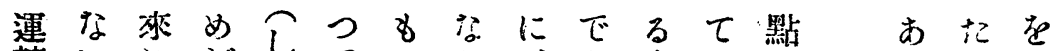

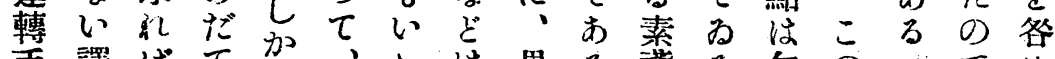

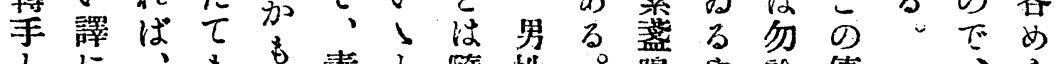

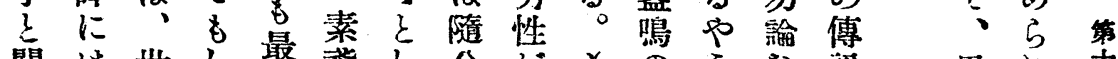

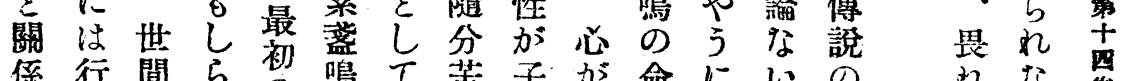

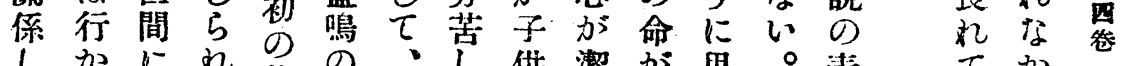

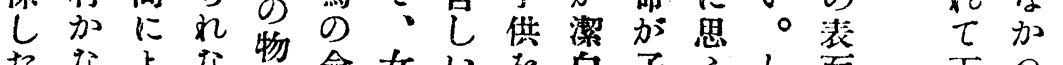

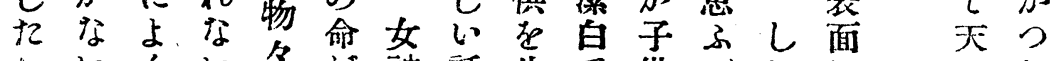

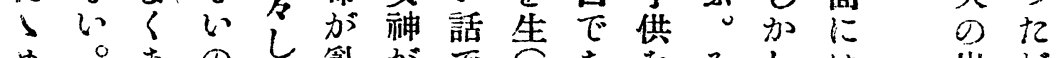

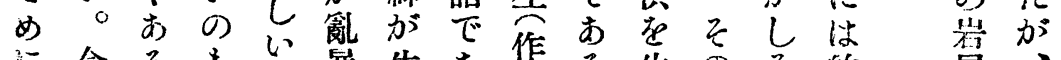

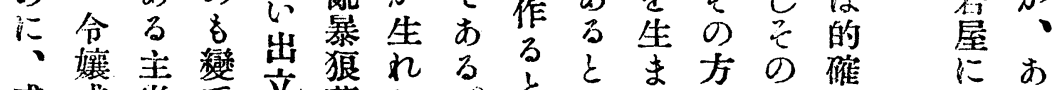

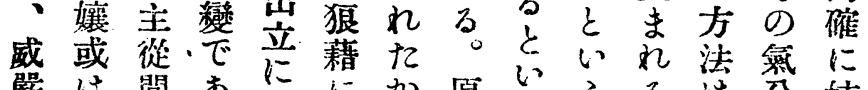

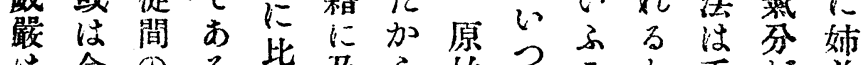

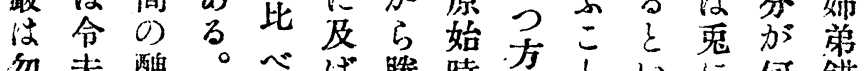
忽夫醜。べば勝時方を゙いに何錯

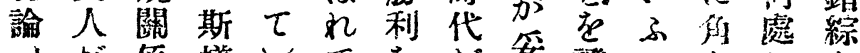

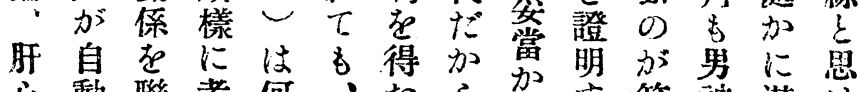

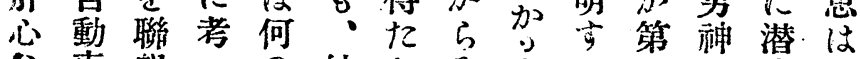

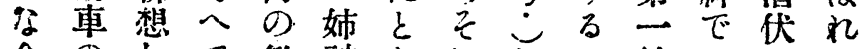

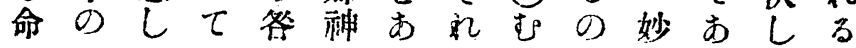

煞ま 策 机与 5 销 机暴 加 $\dot{c}$ 劇 ?L का のな 
ふ活 を る のひ思系お常來こは日性之皆

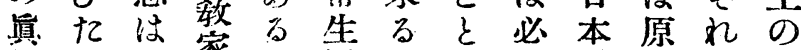
杲相い妃家活乞方市神始は記 表当道殊 の出し話的始述 洞思精德に分な桃もなでめは私 察了科家㨁析らた不るなか到

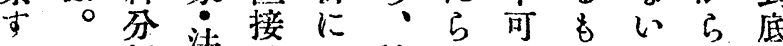

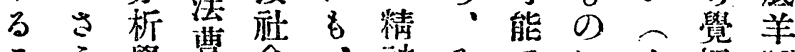

分

$\stackrel{9}{\equiv}$

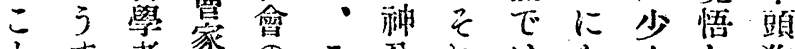

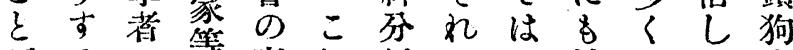

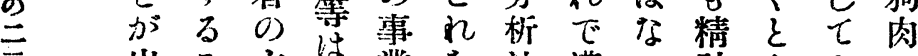
出こ主人業を法霂い神するす

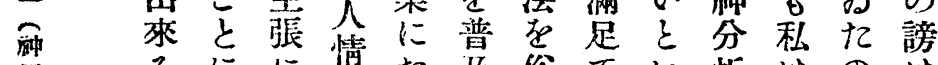

田当にに华た俗で心析はのは でよ二機うし化あふ法さ、で免

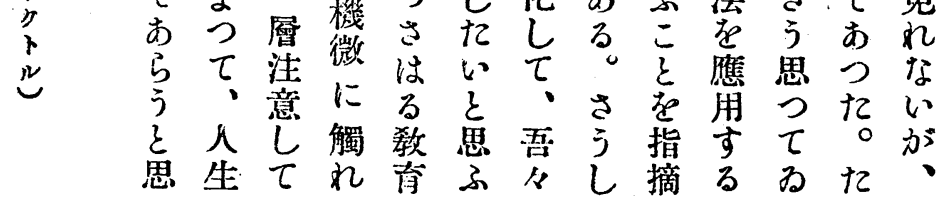

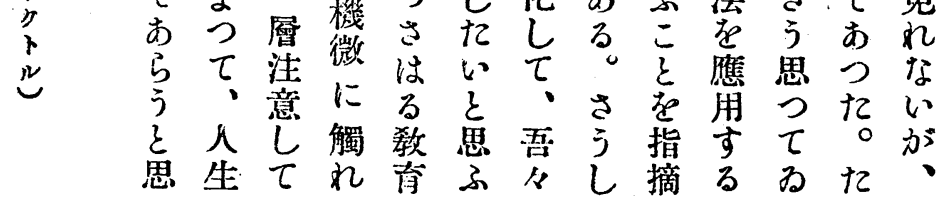

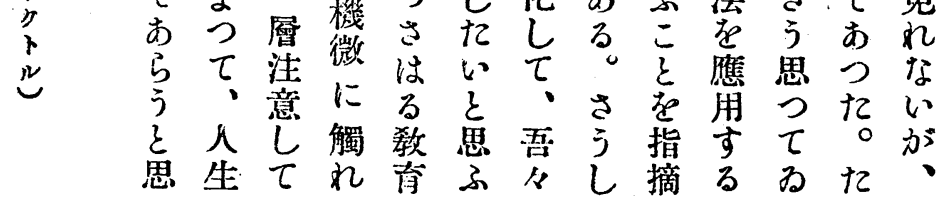

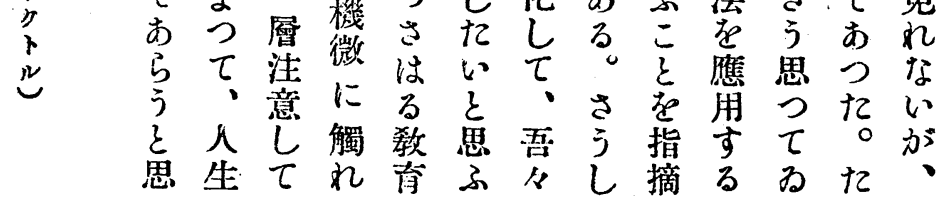

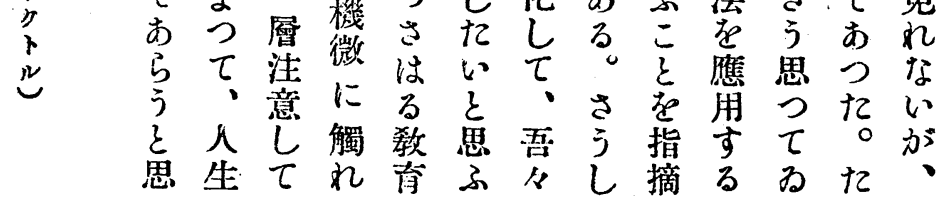

に突はあきの飾すなはれて言事を

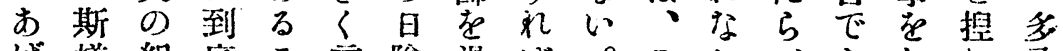
げ樣紀底こ言陰過ば。こ加・おしね分

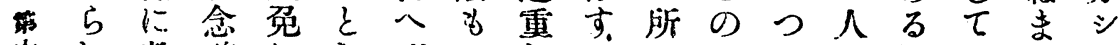

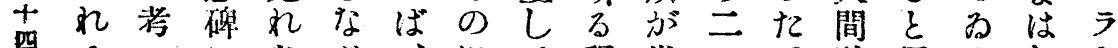

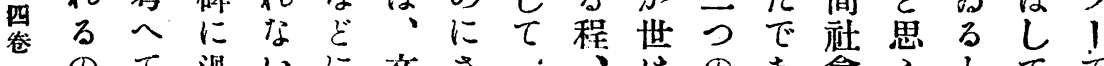

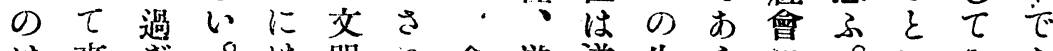

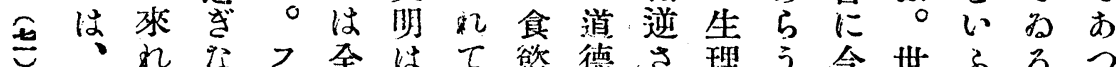
狆な 条ばい口然擮しやをで的。日のや間た

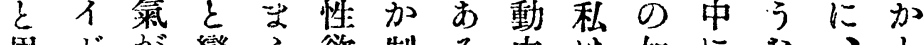
第正つ思

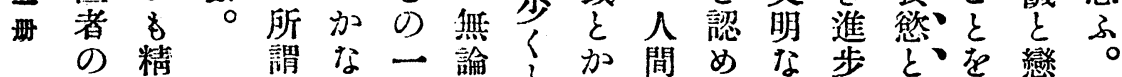
全精神抑い。大道々心能なる 發性言哲

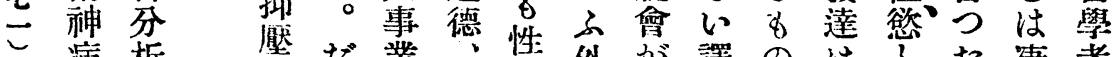

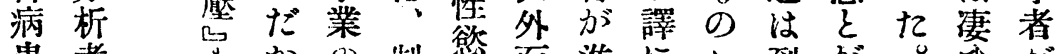

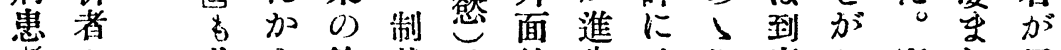
者0)此 5 餘裁は的步は根底な實し屁 や槍 $\sigma$ 衝没、社の發行底見加に心理 天主衝突で大會修達かにらつ至仕屈 
派はに記い析心るた並を洋。呼案才 $と$ 議念て學理。神に謂虫子吸外や 木1論祭は者學こ話飞は、神和を露子

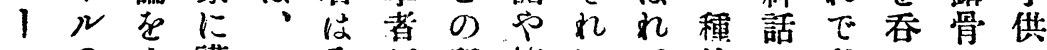

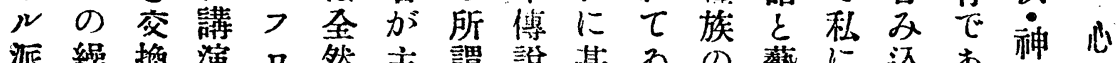

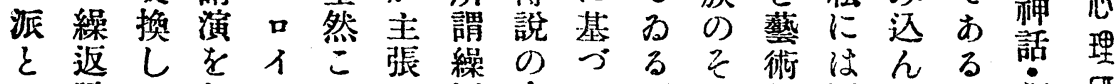

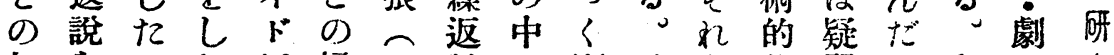

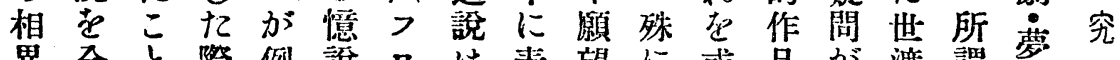

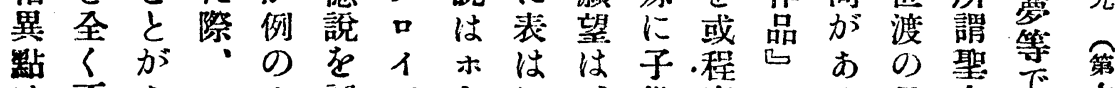

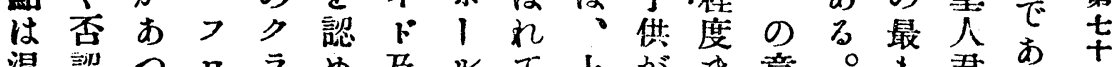

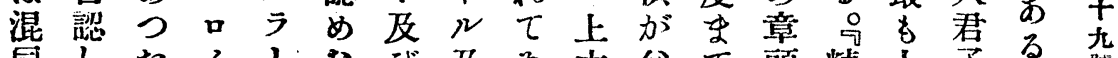

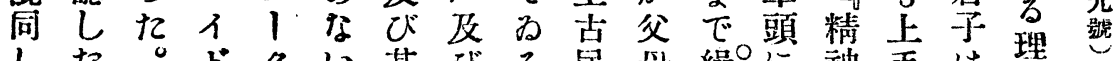

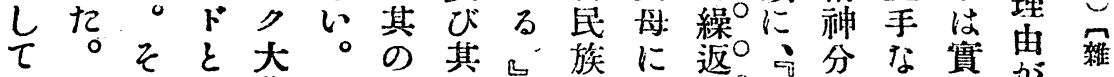

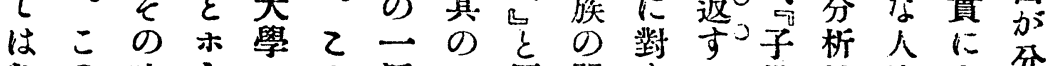

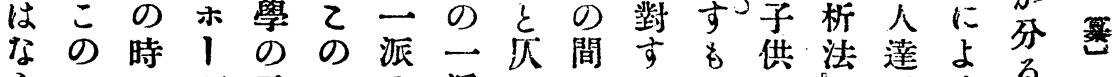

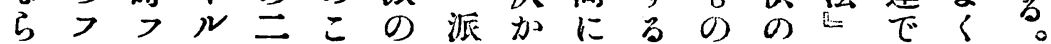

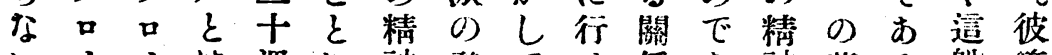
いイイは週に神發ては係あ神著る般等

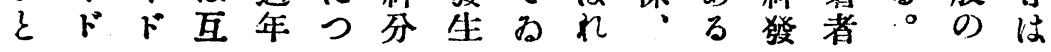

すか 全かと據先人で鬼時に學らが思

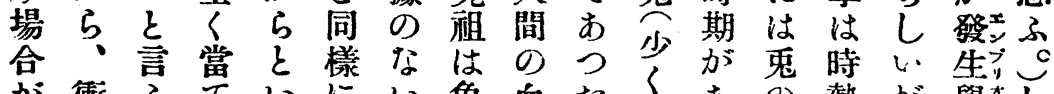

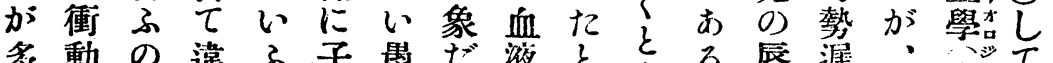

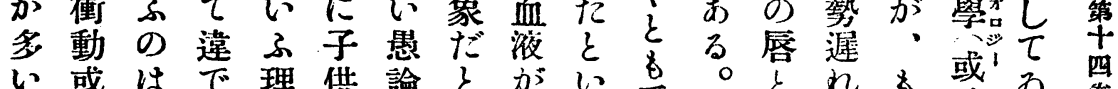
い或はで理供論とか心鬼。方れる或る四

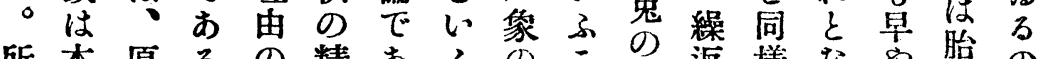

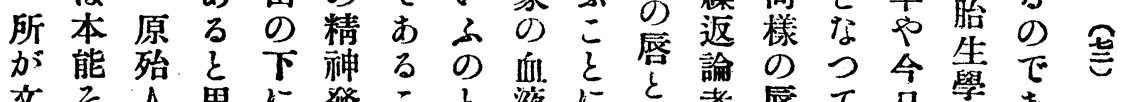

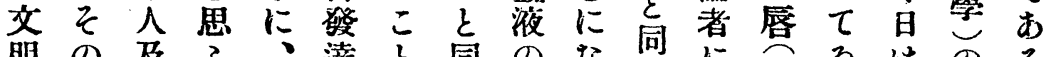

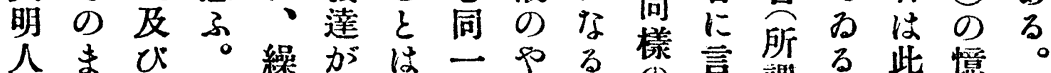

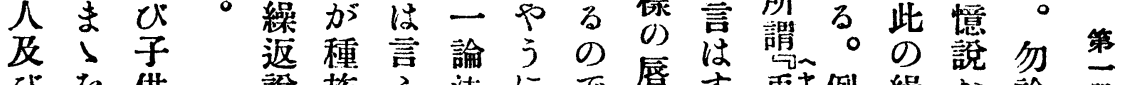
ひ供說族ふ法にで唇夺兔例繰加諭册

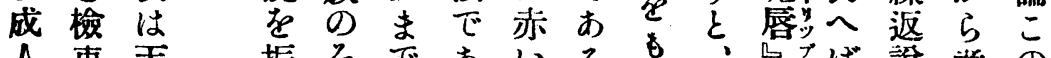

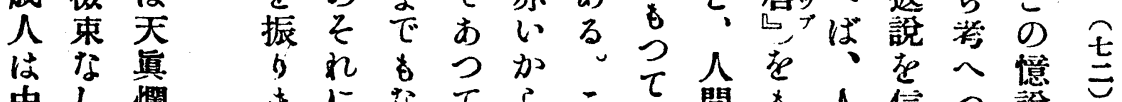

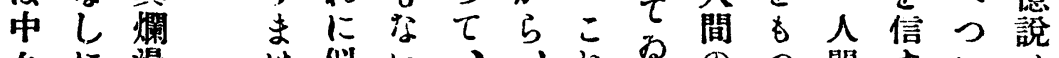

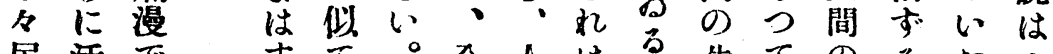
尼活ですて。全人注先てのるた木

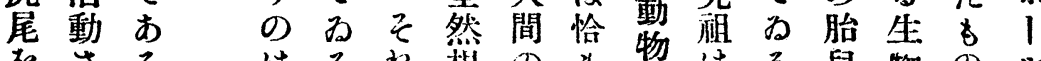

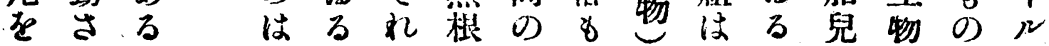


加始つの決人るは辣的力味居偷成出 れ人て言しのる一厴のの譬理の人さ た质る葉てで・見極迫工空壓質とな

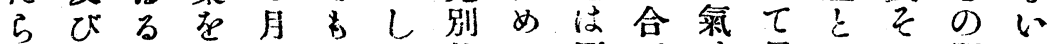

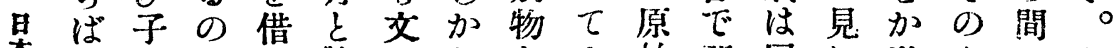

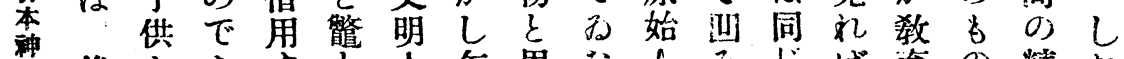

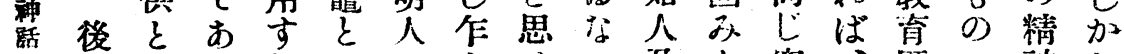
の者同るれののらはい及䇪、壓了神し

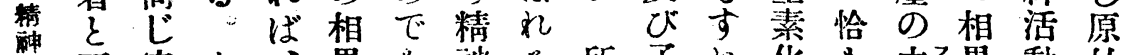

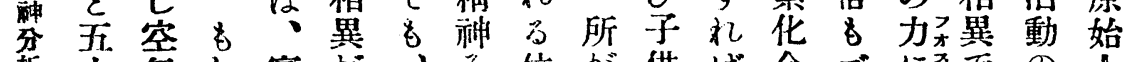
梠十氣し實加、究位が供ば合ゴにでの人

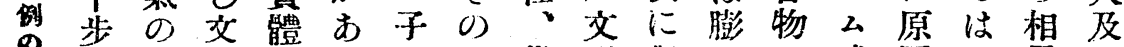

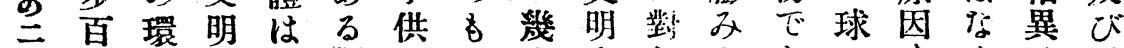

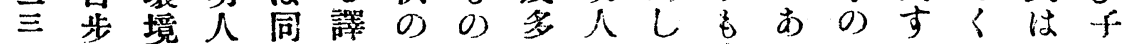

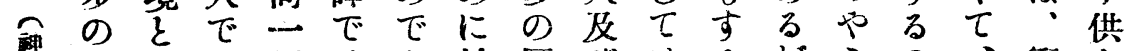

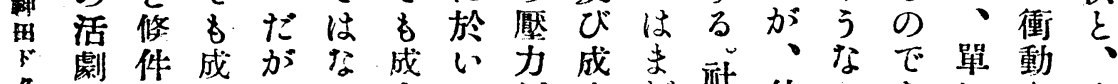

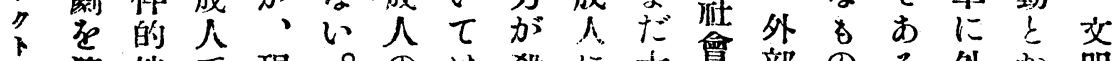

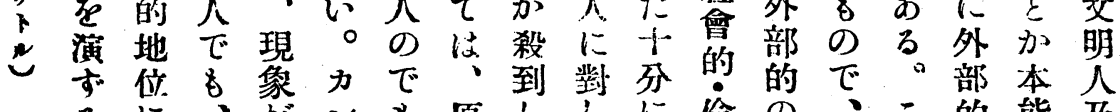
万に、加 て置原違、、始てて辛理盟中れの视

で新發必くな三必の子父公はるお

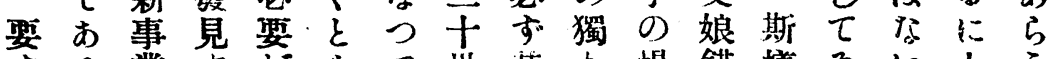

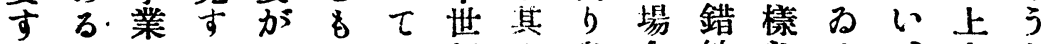
等る。のるあ法表紀の息合綜なる、古と 苗に好こる曹はの嫁子にで譯の交民想

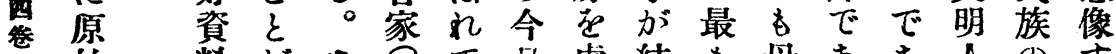

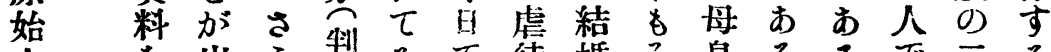
金人出引制るで待婚そ息るるで三る

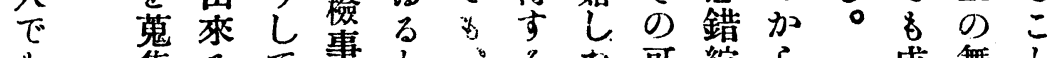

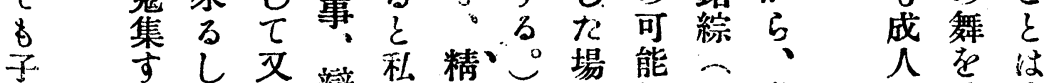

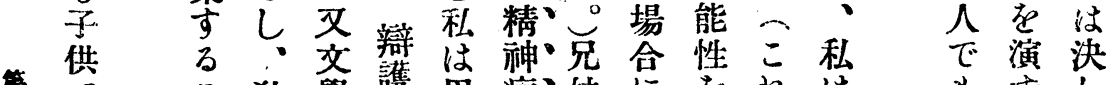

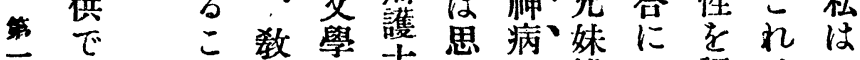

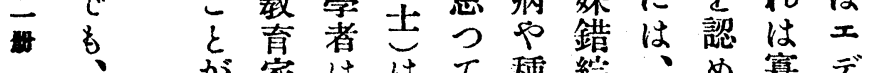

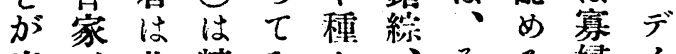

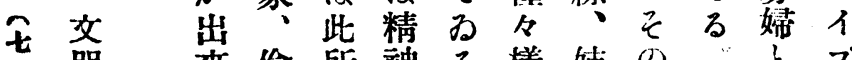

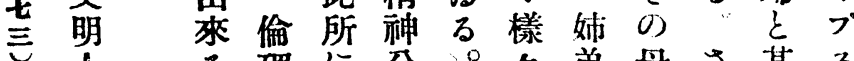

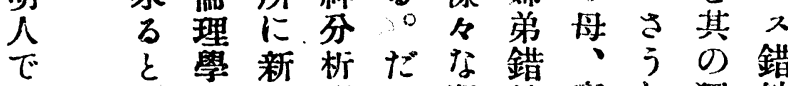
6 思者方者加犯綜赛し獨綜

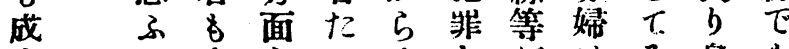
人の亦をる少とが点息す

\& क. L

隨了七 分 の至 面㸐 記供な 事は 以 表分。 賑 はで李 
模るざる的で象ルす

索過る事市力 万人的

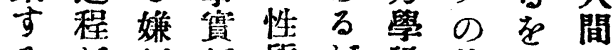

る がが方質が說能得の

の明あ規的從の力る有

感賄了則に來如說加守

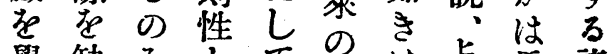

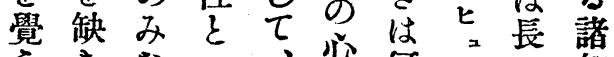
えきな二、心何i心智 し、樣䒚學れ公間能 む動す”性說學著の心艺 万る、との者此聯理 如 の 寸其根觀問想學何 でれの具據筧題說のに あば事備と祭に閨し る人實守し法對 $へ$ 題て ○をよるて文すル統 現し 程設主る心゙あ觀る 時て 品度定観一次 に暗證高せ的の下たに 於中に加ら個解の方解 てに移らる人釋表学釋

と關による新活理量一 試の於引經なた學的派 み度こ整驗ると考引の

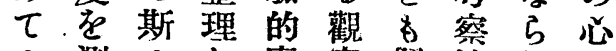
み測るし事察解法し理 る定考正實法釋 の め學 ブ祭正在に考不ん者

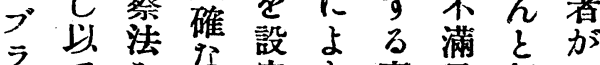
门索定引事足努其

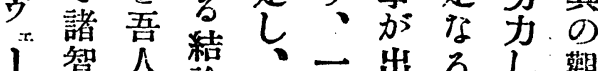
1智人諡、二出るし 觀 心゙能 0 ; 論此尿來点 $\tau$ 察 了統智得事替る㒻乃法亦 ル○能得實則。補るを 小にに死性是はの客

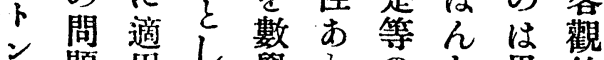

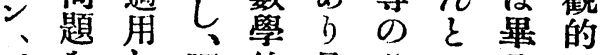
ピ し 而的且心竟总郎

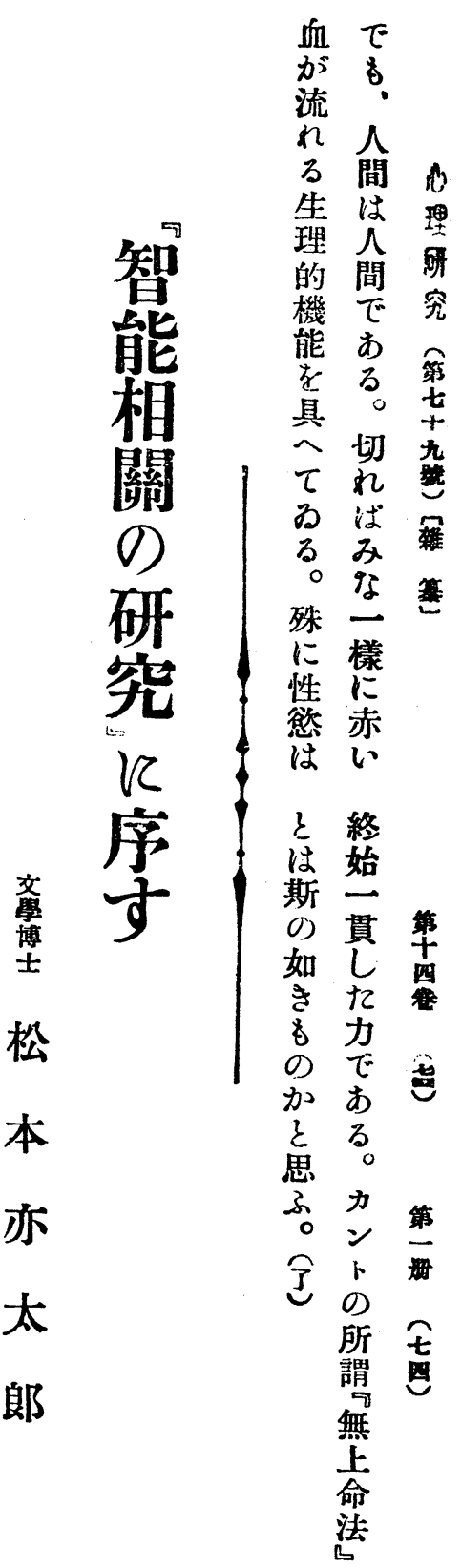
斍
等 松

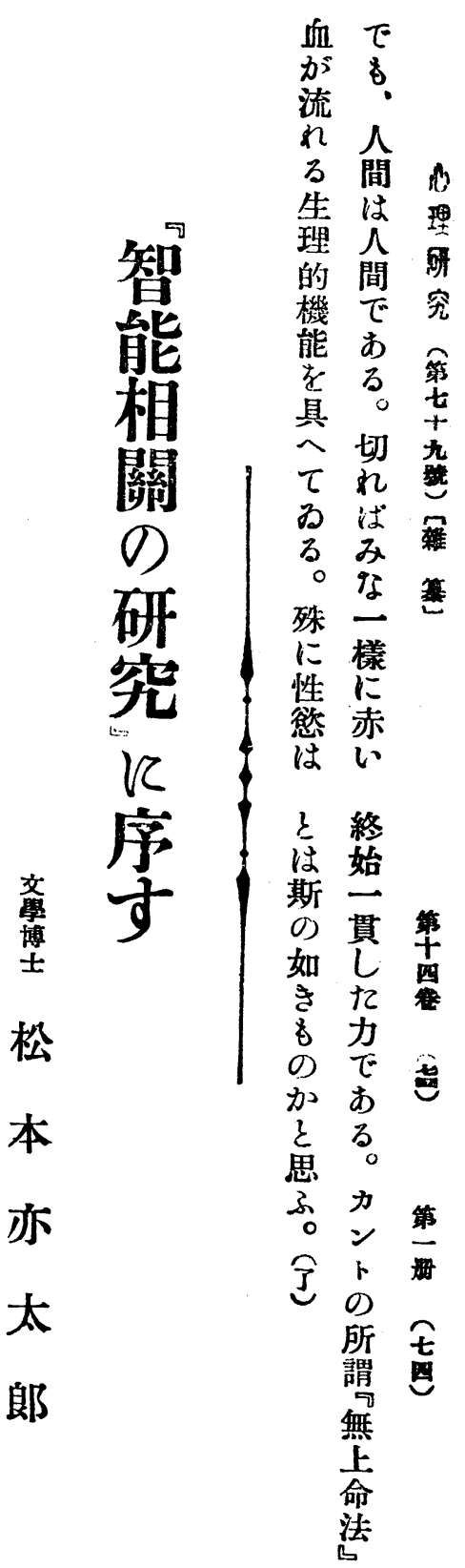

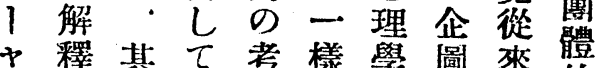
せ ンん相方にあ沈ら忍數 